NBER WORKING PAPER SERIES

\title{
WHY DO SKILLED IMMIGRANTS STRUGGLE IN THE LABOR MARKET? A FIELD EXPERIMENT WITH SIX THOUSAND RESUMES
}

\author{
Philip Oreopoulos \\ Working Paper 15036 \\ http://www.nber.org/papers/w15036 \\ NATIONAL BUREAU OF ECONOMIC RESEARCH \\ 1050 Massachusetts Avenue \\ Cambridge, MA 02138 \\ June 2009
}

This research was carried out with support from Metropolis British Columbia. It could not have been completed without the awesome research assistance from Amit Dhand, Wei Gong, Adam Kowalczewski, Chris-Ann Monteiro, Monica Pu, and Ayaz Warraich. I also thank Joana Lahey for providing her program to randomize resume characteristics, and Rishi Aurora for computing service support. I am grateful to Marianne Bertrand Tarek Hussain, Dan-olof Rooth, Katherine Laird, and Joanna Lahey for detailed suggestions, and to seminar participants at the 'Comings and Goings' conference at the Ottawa Research Data Center, the 2008 Symposium on Findings from Small Scale Experiments in Ottawa, Simon Fraser University, and the University of British Columbia. The views expressed herein are those of the author(s) and do not necessarily reflect the views of the National Bureau of Economic Research.

NBER working papers are circulated for discussion and comment purposes. They have not been peerreviewed or been subject to the review by the NBER Board of Directors that accompanies official NBER publications.

(C) 2009 by Philip Oreopoulos. All rights reserved. Short sections of text, not to exceed two paragraphs, may be quoted without explicit permission provided that full credit, including $\bigcirc$ notice, is given to the source. 
Why Do Skilled Immigrants Struggle in the Labor Market? A Field Experiment with Six

Thousand Resumes

Philip Oreopoulos

NBER Working Paper No. 15036

June 2009

JEL No. J15,J31,J7,K31

\begin{abstract}
Thousands of resumes were sent in response to online job postings across multiple occupations in Toronto to investigate why Canadian immigrants, allowed in based on skill, struggle in the labor market. Resumes were constructed to plausibly represent recent immigrants under the point system from the three largest countries of origin (China, India, and Pakistan) and Britain, as well as non-immigrants with and without ethnic-sounding names. In addition to names, I randomized where applicants received their undergraduate degree, whether their job experience was gained in Toronto or Mumbai (or another foreign city), whether they listed being fluent in multiple languages (including French). The study produced four main findings: 1) Interview request rates for English-named applicants with Canadian education and experience were more than three times higher compared to resumes with Chinese, Indian, or Pakistani names with foreign education and experience (5 percent versus 16 percent), but were no different compared to foreign applicants from Britain. 2) Employers valued experience acquired in Canada much more than if acquired in a foreign country. Changing foreign resumes to include only experience from Canada raised callback rates to 11 percent. 3) Among resumes listing 4 to 6 years of Canadian experience, whether an applicant's degree was from Canada or not, or whether the applicant obtained additional Canadian education or not had no impact on the chances for an interview request. 4) Canadian applicants that differed only by name had substantially different callback rates: Those with English-sounding names received interview requests 40 percent more often than applicants with Chinese, Indian, or Pakistani names (16 percent versus 11 percent). Overall, the results suggest considerable employer discrimination against applicants with ethnic names or with experience from foreign firms.
\end{abstract}

\author{
Philip Oreopoulos \\ Department of Economics \\ University of British Columbia \\ 997-1873 East Mall \\ Vancouver, BC V6T, 1Z1 \\ CANADA \\ and NBER \\ philip.oreopoulos@ubc.ca
}




\section{Introduction}

Recent immigrants to Canada struggle in the labor market. Their unemployment rates compared to similarly-aged non-immigrants are twice as high (Table 1 shows this for immigrants arriving between 1996 and 2000 using the 2001 Canadian Census). ${ }^{1}$ Median wages of recent immigrant workers are also about 35 percent lower compared to native-born workers. Previous research finds little evidence for expecting that this wage gap will significantly narrow with host-country experience. While the immigrant-native wage gap used to disappear (and sometimes even reverse sign) after 10 to 15 years for immigrants arriving prior to the 1970s, wages of immigrants arriving in the 1990s are still about 25 percent lower than wages of non-immigrants even after 2005 (Frenette and Morissette, 2005).

Recent immigrants to other countries such as the United States also experience similar labor market disadvantages (e.g. Lubotsky, 2007), but what is particularly noteworthy in the Canadian case is the fact that their immigration policy focuses on attracting immigrants with superior levels of education, experience, and industry demand to offset an anticipated skilled labor force shortage and encourage economic growth. More than half of today's immigrants enter Canada under a point system, which rates applicants based on their highest degree, language ability, age, whether they have work experience at occupations deemed 'in demand', whether they already have a job offer, have worked or studied in Canada previously, and have cash at hand. ${ }^{2}$ Virtually every

\footnotetext{
1 Picot and Sweetman (2005), Worswick (2004), and Frenette and Morisette (2005) report similar statistics.

${ }^{2}$ See Beach, Green, and Worswick (2006), Antecol, Cobb-Clark, and Trejo (2003) or Borjas (1993) for more details about the Canadian Point System (more formally called Federal Skilled Status Category).
} 
immigrant who enters Canada under the point system now has at least an undergraduate degree. The overall percentage of recent immigrants with an undergraduate degree is about 60 percent, compared to 20 percent for Canadian-born of similar age (Statistics Canada, 2008). Conditioning on highest degree completed, therefore, causes the relative wage gap between recent immigrants and non-immigrants to increase, from 35 percent lower wages for immigrants to 45 percent (Table 1).

Canada has the largest per-capita immigration rate in the world (Dolan and Young, 2004). Policy makers are concerned about the lack of immigrant assimilation because it suggests that recent immigrants are not integrating into the high-skilled labor market, despite effort to attract immigrants who will. This raises questions about the role immigration plays in providing Canada with a source of highly skilled individuals to boost economic growth. It also has important implications for the use of government transfer programs, such as social assistance and child tax benefits, as well as for income tax revenues. A number of other countries such as the United Kingdom, Spain, and Germany are also considering or in the process of bringing in a point system as part of a plan to shift their immigration policies more towards a skill-based focus. The international competition to attract skilled immigrants is evidently increasing and more attention is being devoted to a point-system approach to evaluate the desirable characteristics of prospective immigrants. While the United States has traditionally emphasized more the role of family reunification in its immigration policy, some debate has initiated over possible adoption of a point system. So it is also worthwhile to

Language ability is evaluated based on an applicants "International English Language Test System (IELTS) score, or by submitting a written explanation detailing training in and usage of English Language. If an immigration officer believes the written explanation is inadequate, he or she can require the applicant take the IELTS instead. 
investigate, from the perspective of other countries, why Canada's point system does not appear to be having its desired effect.

The usual suspects to explain the gap include the possibility that employers do not value foreign education as much as they value Canadian education. The point system treats any degree from any institution the same. Foreign experience may also be treated as inferior to Canadian experience, since less is known about the employer and tasks involved. Other possibilities are that cultural and language differences have grown as the proportion of applications from Europe has decreased and the proportion from Asia and the Pacific Coast has increased. The point system places no role on an applicant's understanding of social etiquette and concerns about language proficiency may remain.

Previous studies have attempted to explain the immigrant-native wage gap using a Blinder-Oaxaca-type decomposition methodology (Aydemir and Skuterud, 2004, Frenette and Morissette, 2053, Green and Worswick, 2004, Schaafsma and Sweetman, 2001, Lalonde and Topel, 1992, and Ferrer and Riddell, 2008). The typical approach is to first predict immigrant wages based on having similar characteristics as nonimmigrants, such as total years of experience, schooling, city of residence, and local economic conditions. Then, the difference between an immigrant's actual and predicted wage is regressed on his foreign background to determine which of these characteristics have the greatest explanatory power. My reading of this literature is that there is general consensus around the conclusion that the immigrant-native wage gap in Canada exists mostly because of lower returns to foreign experience, especially among immigrants from Asia and the Pacific. 
The Blinder-Oaxaca decomposition approach, however, does not offer details about what underlies these relationships. Lack of data about language ability, quality of education, quality of experience, and other hard-to-measure skills prevent us from telling why employers value foreign experience less. It also cannot assess the extent to which differences in wages are driven simply by taste-based discrimination, since it's impossible to rule out unobserved characteristics explain these results.

This study adopts a completely different methodology to investigate why Canadian immigrants arriving under the point system struggle in the labor market. Thousands of resumes were sent online in response to job postings across multiple occupations in the Greater Toronto Area after randomly varying characteristics on the resume to uncover what affects employer's decisions on whether to contact an applicant. The resumes were constructed to plausibly represent recent immigrants under the point system from the three largest countries of origin (China, India, and Pakistan) and Britain, as well as non-immigrants with and without ethnic-sounding names. In addition to names, I randomized where applicants received their undergraduate degree, whether their job experience was gained in Toronto or Mumbai (or another foreign city), whether they listed being fluent in multiple languages (including French), whether they had additional education credentials, and whether they listed active extra curricular activities. The approach provides a way to estimate what resume elements affect callback rates and compare different theories behind the immigrant-native gap. I also recorded characteristics of the job and employer to determine whether the effects vary across type of firm or evaluator. 
My approach extends the work of Bertrand and Mullainathan (2004) who found that resumes sent to blue-collar jobs in Boston in Chicago with white-sounding names generated callbacks about 50 percent more often than the same resumes sent with blacksounding names. The first studies to apply this type of methodology used pairs of trained 'auditors' instead of resumes to test for discrimination (Riach and Rich, 2002, provide a review of this literature). Traditional audit studies try to match individuals in all respects except the variable of interest, usually race, ethnicity, or gender, to rent an apartment, buy a house, or apply for a job (e.g., Fix and Struyk 1993). Resume audits have the advantage that they provide more control over the information employers use to make a decision. Although these types of studies only measure the interviewing stage of the hiring process, they allow far larger samples to be collected, and thus more degrees of freedom to examine interactions and sup-groups.

The only existing Canadian audit study that I am aware of examined response differences after calling 237 employers to ask whether job openings are still available using auditors with "Canadian", Slavic, West-Indian, or Indo-Pakistani accents. Those with typical Canadian accents were told jobs were available 85 percent of the time. Those with Slavic accents were told jobs were available 52 percent of the time, and those with Indo-Pakistanni accents were told jobs were available 47 percent of the time (Henry and Ginzberg, 1985). Another related paper looked at callback differences between Middle Eastern and Swedish-sounding names (in Sweden). Carlsson and Rooth (2007) found callback rates were 50 percent higher for equivalent resumes with Swedish names, and that the effects were higher when the employer was a small firm and the recruiter was 
male. My study is the first to consider many randomized characteristics on the resume at once, to help explain why immigrants fare poorly in the labr market.

As discussed more below, I find almost as much name-discrimination in my study as Bertrand and Mullainathan (2004) find between Black and White-sounding names. Applicants with English-sounding names with Canadian education and experience received callbacks 40 percent more often than did applicants with Chinese, Indian, or Pakistani names. Conditional on listing 4 to 6 years Canadian experience, being foreign educated (whether at a highly ranked school or not) did not affect callback rates substantially. But changing only the location of the applicant's job experience, from Canadian to foreign, lowered the callback rate further from about 10 percent to 5 percent. Adding more language credentials, additional Canadian education, or extracurricular activities had little impact on these overall results. The effects were almost the same whether jobs applied to required more or less social or language skills. Callback differences mostly went away when comparing native applications to British immigrants. Overall, the results suggest considerable employer discrimination against ethnic Canadians and immigrants. I discuss more the implication of these results below and what behavior might underlie these results.

\section{Research Design}

Thousands of randomly created resumes were sent by email in response to job postings across multiple occupations in the Greater Toronto Area between April and 
November 2008 (data and examples are provided in the electronic appendix). ${ }^{3}$ The resumes were designed to plausibly represent typical immigrants that arrived recently under the Canadian Point System from China, Pakistan, and India (the current top three source countries) and Britain, as well as non-immigrants with and without ethnically sounding names. They were constructed after consulting actual resumes of recent immigrants and online submissions. ${ }^{4}$ The sample of jobs I applied to represent all jobs posted during this period that accepted applications via direct email and generally required three to seven years of experience and an undergraduate degree. Positions that specifically required at least a graduate degree, North American experience or education, or French as a second language were ignored.

With few exceptions, four resumes were sent to each employer over a 2 to 3 day period in random order. The first represented an applicant with an English-sounding name, Canadian undergraduate education, and Canadian experience (Type 0). The second resume had instead a foreign-sounding name (Chinese, Indian, or Pakistani), but still listed Canadian undergraduate education and Canadian experience (Type 1). The third resume included a foreign-sounding name, foreign undergraduate degree, and Canadian experience (Type 2). The fourth included a foreign-sounding name, foreign education, and some (Type 3 ) or all (Type 4 ) foreign experience. ${ }^{5}$ I also randomized each applicant's alma mater, whether the applicant listed being fluent in multiple

\footnotetext{
3 Two examples are shown at the end of this paper. Files of all resumes sent are available by request. ${ }^{4} \mathrm{~A}$ human resource director at a job placement organization in Bangladesh provided very helpful advice and a comprehensive set of annonymized resumes of individuals who qualified under the Point System to immigrate to Canada. I also consulted resumes posted on www.workopolis.com and www.jobbank.ca.

${ }^{5}$ Resume sets with more than one applicant with foreign experience or education from the same country were excluded.
} 
languages (including French), whether they had additional Canadian education credentials, and whether they listed active extra curricular activities.

The English-sounding names on Type 0 resumes were picked randomly from a list of the most popular Anglophone surnames in Canada (Smith, Martin, Brown, Wilson, and Johnson), and matched randomly with one of four possible male names (Greg, John, Matthew, or Michael) or four possible female names (Alison, Carrie, Emily, and Jill) used previously by Bertrand and Mullainathan (2003). ${ }^{6}$ Resumes with foreign education or experience from Britain had the same names. The other resumes of Type 1 to 4 had names picked randomly among a list of 24 popular male and female names from China, India, and Pakistan. ${ }^{7}$ Table 2 shows the number of resumes sent by name and type. Email addresses were set up for all 32 names using both gmail.com and yahoo.ca accounts.

Work experiences were constructed from actual resumes accessible online. The descriptions were sufficiently altered to create distinct sets that would not be associated with actual people, but I also tried to maintain original overall content and form. Each resume listed the job title, job description, company name, and city location for an applicant's three most recent jobs covering 4 to 6 years, with the first job beginning in the same year as the applicant's undergraduate degree completion. The city listed was

${ }^{6}$ The common Canadian surname list comes from an article dated July 26, 2007 by the Canadian Broadcasting Corporation, accessible on March 12, 2008 at www.cbc.ca/news/background/namechange/common-surnames.html. The article mentions the list comes from infoUSA, "which claims to have put together a directory of every telephone listing in Canada".

${ }^{7}$ Chinese names were picked from a most common names list on the website http://zhidao.baidu.com/question/41504421.html. The web page cited the National Citizen Identity Information Center of China as the source. Indian names were gathered from the web page http://hinduism.about.com/library/babynames/bl-babynames-index.htm, and with consultation with one of my research assistants with Indian heritage. I saved these web pages, which are available on request. 
always the same (except for Type 3 resumes). ${ }^{8}$ Experience sets were constructed for 20 different occupation categories, almost all the same ones used by the online job site workopolis.com. ${ }^{9}$ Within each category, I created four different experience sets, whose job titles and corresponding job descriptions were randomly assigned to one of the four resumes sent to a single employer. ${ }^{10}$ It is worth emphasizing that this randomization not only made years of experience the same across immigrant and non-immigrant resumes (on average), but it also made the description of this experience the same. In addition, company names were also independent of resume type for about half the sample. International companies were chosen wherever possible to keep the experience sets identical across immigrant and non-immigrant resumes except for location (for example ABC Inc., Toronto versus ABC Inc., Mumbai). In cases where no obvious international company was available, I picked closely related companies in size and industry. Interestingly, the overall results using identical company names were the same as those using different names (I discuss this more below).

Since virtually all immigrants that arrived recently under the point system had at least a bachelor's degree, all resumes generated in this study did so as well. A job posting's occupation category determined the set of degrees to randomly pick. For example, resumes generated for a position as a Financial Analyst had either a Bachelor of Arts in Economics or one in Commerce while those for a Software Developer position had a Bachelor's degree in Computer Science or one in Computer Engineering. Alma

\footnotetext{
8 The city was either Mississauga, Toronto, Beijing, Shanghai, Guangzhu, New Delhi, Mumbai, Punjab, or London.

${ }^{9}$ The categories were administrative, insurance, arts and media, biotech-pharmaceutical, marketing, ecommerce, production, education, retail, maintenance, programmer, civil engineering, electrical engineering, executive, finance, technology, human resources, computer, healthcare, and hospitality.

10 The main sites I used for this were workopolis.com and jobbank.ca
} 
mater was picked randomly from a list of about four universities in the same country as the applicant's corresponding name and in the same proximity to the applicant's location of experience. About half of the universities were listed in the 2008 QS World University Rankings' top $200 .^{11}$ The other universities were less prestigious. Manipulation of this characteristic helps examine whether employers prefer applicants with degrees from Canada even in cases where, all else constant, other applicants have foreign degrees from more selective or better quality schools. It is interesting to note that under the point-system an applicant receives the same number of points for a Bachelor degree, regardless of where he or she received it.

To assess whether additional Canadian educational credentials may offset lower callback rates from having foreign experience or foreign schooling, 20 percent of resumes, except those of Type 4, were randomly assigned Canadian Master's degrees from universities nearby Toronto. ${ }^{12}$ Masters degrees were occupation specific and completed during the same three-year period as the applicants' most recent (Canadian) experience, so that it looked like the applicant was enrolled part-time while working fulltime. Some job postings also indicated that specific certificates or credentials (other than a Bachelor's degree) were required, or at least strongly preferred (two common instances were Certified General Accountant (CGA) and software experience such as Flash). For job postings that required a particular certificate (13 percent of my sample), I listed this requirement on each of the four resumes sent. For job postings that mentioned a preference for a particular certificate (4 percent of my sample), I randomly assigned it to one or two of the four resumes sent. These procedures provide another method for

\footnotetext{
11 See www.topuniversities.com.

${ }^{12}$ I note in the results section below that callback differences between Type 4 and other type resumes are about the same whether Masters degrees are listed on the other type resumes or not.
} 
exploring the potential effects of certification on reducing callback gaps between applicants with and without foreign backgrounds.

Language skills and extra-curricular activities were also manipulated to help explore whether language or cultural concerns underlie callback differences. I randomly selected 20 percent of resumes to list fluency in multiple languages. Resumes with English soundings names listed fluency in English and French. The other resumes listed fluency in English, French, and the applicant's mother tongue (Mandarin, Cantonese, Hindi, or Punjabi), depending on the applicant's ethnic origin of name. In addition, 60 percent of resumes listed active extra curricular activities. One of three possible sets was chosen listing characteristics such as volunteer initiative (e.g. Big Brother/Sister, Habitat for Humanity), social interests (e.g. competitive squash player, classical pianist) and proactive work skills (e.g. excellent common sense, judgment, and decision-making abilities). Table 3 shows average frequencies of these and other characteristics on the resumes sent, for each type.

Clearly resumes had to look different when sending to the same employer, so I also randomized each applicant's cover letter (a short, general message sent as a part of the email text), and the email subject line and the resume file name (resumes were saved as pdf files unless word documents were specifically requested). I randomized each resume's layout, residential address and telephone number (all possibilities were within the Greater Toronto Area, with one apartment address and four home addresses in Mississauga, Brampton, and Toronto). Each applicant listed three previous jobs, with earlier years of experience being over 2, 3, or 4 years for each particular job, and with the most recent job always being listed as starting from 2006 to present. I randomized each 
applicant's email address (s.shreya6@gmail.com or shreya.sharma48@yahoo.ca for example) and resume profile, which was listed near the top of the resume. Profiles mentioned general and specific skills, such as "highly motivated" and "fast learner". Some bullet points were occupational specific ("six years experience in customer service and sales environment", for example). Within each occupation, profiles were selected randomly from 5 sets.

A program by Lahey and Beasley (2007) was used to randomly select the characteristic codes of each resume. Microsoft Office was then used to transform these choices into text and mail-merge them onto actual resume templates. Some resume sets were dropped to avoid repeating names sent to the same employer. Research Assistants developed a program to make the data collection process more menu-driven. When a job posting was identified for the study (from a newspaper ad or internet site), a research assistant would open a dialog window prompting for the job's corresponding occupation. Phone numbers or email addresses on the post were used to check that someone had not applied to this employer previously. A second window allowed the user to enter the job title, the job posting's source, the company name, contact information, and whether additional certificates needed adding. The program then updated the data collection spreadsheet and created four resumes that could be edited for cosmetic quality (e.g. to ensure they fit cleanly on one or two pages). The output also included instructions for what cover letter, subject line, and file name to use. The resumes were saved as pdf files and emailed from the addresses of the corresponding names to the employer over a 2 to 3 day period in random order. Any applications whose corresponding email bounced, indicating it was never received, were dropped from the sample. 
Five telephone numbers and two email accounts for each name were set up to collect employer responses. Employers that telephoned an applicant received the same automatically generated message mentioning the number dialed and a request to leave a message. Messages and emails were recorded and redirected to a single email address. Responses were classified as callbacks if the employer requested an applicant to contact them (not just for clarification). Responses were classified as requests for interviews if one was specifically mentioned. Research assistants also guessed the contact's gender and ethnicity based on accent or name. If the person calling back was likely the person who assessed the resumes, this information allows me to analyze interaction effects between resume type and some of the assessor's characteristics. Employers that contacted an applicant twice were contacted themselves during off-hours by email or phone-message and told that the applicant had accepted another position and was no longer looking for employment.

I also recorded measures of language and social skills associated with each job using the Occupational Information Network (O*NET). The purpose was to examine whether callback differences across resume types differ by the extent to which jobs require use of language or social skills. For each job title, I recorded the O*NET's corresponding skill measure for speaking, writing, social perceptiveness, and social orientation. ${ }^{13}$ Each variable ranges from possible values of 0 to 100 . I also measured whether a job was classified as "In-demand" or not, so see whether greater competition for employees reduces callback differences.

\footnotetext{
${ }^{13}$ Occupations were matched to these skill measures using $0^{*}$ NET's web site, http://online.onetcenter.org/
} 
With random assignment, simple comparisons of callback rates can identify relative effects of the different resume characteristics. I also consider a more detailed analysis using the following linear probability model:

(1) $y_{i j}=\delta_{0}+\delta_{1} \operatorname{Re}$ sume_type $_{i j}+\delta_{2} \mathrm{X}_{\mathrm{ij}}+\delta_{3}\left[\operatorname{Re}\right.$ sume_type $\left._{i j} * \mathrm{X}_{\mathrm{ij}}\right]+e_{j}+e_{i j}$

Where $y_{i j}$ is an indicator variable for whether resume $i$ sent to job posing $j$ generated a call back, Re sume_Type $e_{i j}$ is an indicator variable for resume type, with the indicator for Type 0 being omitted. $X_{i j}$ is a vector of other resume characteristics. Equation (1) allows for interactions between resume type and other characteristics. This allows me to estimate, for example, whether callback differences between resumes with English and Chinese-sounding names become smaller when additional language skills or educational credentials are listed. The $e_{j}$ 's are job fixed effects that lead to analyzing average callback differences for resumes sent to the same employer (estimates of $\delta_{1}$ remain unbiased whether these effects are accounted for or not). $e_{i j}$ is the error term. Standard errors are corrected for possible heteroskedasticity and clustering by job.

\section{Results}


Table 4 shows the main results. ${ }^{14}$ The baseline callback rate for Type 0 resumes, with English-sounding names, Canadian experience, and Canadian education is 15.8 percent (Column 1). Changing only the name to one with Indian origin lowers the callback rate by 3.7 percentage points, to 12.1 percent (s.e. $=1.9$ percentage points), and changing it to one with Chinese or Pakistani origin lowers it slightly more, to 10.8 percent and 11.0 percent respectively. Overall, resumes with English-sounding names are 40 percent more likely to receive callbacks than resumes with Indian, Chinese, or Pakistani names (Column 6). For comparison, Bertrand and Mullainathan (2003) find that resumes with similar English sounding names are 50 percent more likely to receive callbacks than resumes with African-American-sounding names sent to employers in Boston and Chicago (4 percent versus 8 percent respectively). ${ }^{15}$

There does not appear to be any difference in callback rates between Type 1 and Type 2 resumes, which systematically differ only by whether they list a Bachelor's degree from a Canadian (Type 1) or foreign (Type 2) university. Both sets of resumes include Canadian names and foreign experience. Thus, conditional on listing 4 to 6 years of Canadian experience, employers do not seem to care whether an applicant's education is from a foreign institution or not, when deciding whether to contact them for an interview.

\footnotetext{
14 Appendix Table 1 shows similar results using other outcome variables than the general callback rate: whether a resume generated a specific interview request, a second callback, or a second callback conditional on a first callback. Of particular note is the finding that receiving a second callback after receiving a first callback (perhaps indicating exceptional interest) occurs less often for resumes with foreign experience or education.

15 I also explored whether the results for resumes with Chinese-sounding names change when using only Chinese last names instead of both Chinese last and first names. Many second-generation Chinese adopt and use and English-sounding name (such as Monica Liu instead of Min Liu). Appendix Table 2 shows results comparing callback rates for different resume types with Englishsounding names, all Chinese-sounding names, and English-Chinese names. The rates are slightly higher for resumes with English-Chinese names instead of Traditional-Chinese names, but not by much, and these differences are statistically insignificant.
} 
In contrast, switching from job experience acquired in Canada to job experience acquired from a foreign country seems to matter a lot. Types 2,3 , and 4 resumes all list foreign names and foreign degrees. The experience descriptions are also identical, but Type 4 resumes list previous job experience with companies located in foreign cities (e.g. $\mathrm{ABC}$ Inc, Shanghai instead of $\mathrm{ABC}$ Inc, Toronto) and Type 3 resumes list foreign cities for 2 of the three previous jobs (the most recent job is listed being in Toronto). The callback rate for resumes that list almost all job experience from India, China, or Pakistan drops 2.6 percentage points compared to resumes with all Canadian experience (from 11.4 percent to 8.8) percent, shown in Column 6. Callback rates drop 6.2 percentage points for resumes listing only foreign job experience. ${ }^{16}$ Interestingly, The resumes that list only British experience do not generate any significant fall in callback rates compared to Type 0 Canadian resumes (14.1 percent compared to 15.8 percent, as reported in Column 5). ${ }^{17}$

\footnotetext{
16 Type 4 resumes also differ from other types in that they list no Canadian masters degrees (because the resumes would look strange with masters degrees acquired in Canada during a period while working outside Canada). But dropping the $20 \%$ of Type 0 and Type 4 resumes with masters degrees makes no difference to these results. The callback rates, corresponding to Column 6 , for the sub sample without masters degrees are 15.9 percent, 11.4 percent, 12.4 percent, 8.4 percent, and 5.2 percent for Types 0 through 4 respectively. These results line up with the finding that masters degrees have little effect on the callback rate (shown in Table 5). Type 4 resumes with all foreign experience also may raise concern by an employer whether the applicant has the proper working visa status to work in Canada. However, if this explained the drop in callback rates for resumes from India, China, and Pakistan, one would also expect to observe a similar drop for resumes from Britain. 17 Type 3 and Type 4 resumes list foreign experience, but in about half the sample company names and job descriptions are identical with those in Type 2 resumes (with Canadian experience). For example, some resumes list experience with ABC Inc, Toronto, while others list experience with ABC Inc, Shanghai. Results using resumes with the same company names are similar to those using samples whose company names are different (but whose job descriptions are identical). More specifically, the callback rates for Type 3 and 4 resumes listing experience with international companies (that could instead be used for resumes with Canadian experience) are .071 and .068 respectively. The callback rates for Type 3 and 4 resumes listing local foreign company names are 0.099 and 0.040 respectively.
} 
For the remaining results, Type 2, 3, and 4 resumes exclude applicants with British experience and education, in order to focus on comparisons with the three largest immigrant groups from India, China, and Pakistan.

Table 5 shows callback differences after conditioning on other resume characteristics. Column 1 shows the baseline results, repeated from Column 6 in Table 4 . Column 2 shows coefficient estimates from regressing callback rates on indicators for resume type and fixed effects for job position. The fixed effects make the callback comparison the average tendency for an employer to contact one resume type over another. Column 3 shows estimated callback differences after conditioning on gender, whether the resume included a degree from a high ranking university, whether multiple languages were listed, and whether a Canadian masters degree was listed. Column 4 adds job position fixed effects to the empirical specification. These additional conditioning variables make no substantial difference to the callback comparisons. This is expected, since these variables are independent of resume type assignment. What is surprising is that the coefficients on these other resume characteristics are all statistically insignificant, except possibly for gender. Callback rates for resumes listing female are marginally higher than those listing male, but rates between resumes with and without listing active extracurricular activities, and between resumes listing fluency in multiple languages (including French) and those that do not are about the same. Even resumes with Masters degrees do not generate more callbacks than resumes without. I interpret these results as suggesting that experience plays far more an important role when applying to jobs requiring 3 to 7 years experience. Or, perhaps employers do not look beyond an applicant's general experience and education in determining whether to callback. 
Unfortunately, the results also imply that an applicant's name matters considerably more than his additional education, multiple language skills, and extracurricular activities.

While these other resume characteristics to not appear to help for the sample as a whole, perhaps they matter to immigrants in particular. Table 6 shows results from regressing callback status on resume characteristics separately by resume type. Females with English-sounding names are 3.3 percentage points more likely to receive a callback than males with English-sounding names (Column 2). For applicants with foreign sounding names, gender did not make a difference. This may be because employers could not distinguish gender from some of the foreign names listed on the resumes. Column 3 shows that callback rates are higher among Type 1 applicants with degrees from more prestigious Canadian universities, even though no such relationship holds for Type 0 applicants with English-sounding names instead of foreign-sounding ones. Notably, callback rates are no different between applicants with foreign degrees from high-ranking universities and applicants with foreign degrees from less known schools. ${ }^{18}$ Listing extracurricular activities, fluency in French and other languages, or a Canadian Masters degree does not appear to have any impact on callback rates, whether for immigrant or non-immigrant resumes.

Table 7 shows callback rates separated by the five largest occupation categories in my sample. The overall results are not driven by one or two particular occupations. The finding that callback rates fall from listing foreign-sounding names and foreign experience occurs across all categories. The callback ratio of Type 0 resumes over Type 1 resumes, for example, is $2.1,1.5,1.4,1.2$, and 1.5 times greater for resumes in

\footnotetext{
18 Appendix Table 3 shows a more detailed breakdown of callback rates by resume type and university degree. A Degree from China's top ranked university (Peking University), for example, generated no higher callback rates than did a degree from Lanzhou University.
} 
Administrative, Finance, Marketing, Programmer, and Retail job categories respectively. All five categories show no substantial difference in callback rates between Type 1 resumes (with degrees from Canada) and 2 resumes (with degrees from foreign institutions). There is some callback evidence that callback rates for programming jobs are not very different. These jobs require strong cognitive abilities, but do not require as much social interaction skills.

Table 8 examines the role additional Canadian education credentials may play in helping offset less employer interest in foreign applicants. As mentioned in Section II, certificates (such as Certified General Accountant) were added to all four resumes when a job posting said they were required (13 percent of my sample), and added randomly to one or two of the four resumes sent to an employer when a job posting said they were preferred (4 percent of my sample). Callback rates for resumes listing required certificates are certainly higher than rates for resumes sent to jobs with no specific certificate requirement (e.g. 26.2 percent versus 14.2 percent for Type 0 resumes), but this boost occurs more for non-immigrant resumes and applicants with English-sounding names than for immigrant resumes and applicants with ethnic-sounding names. The callback rate for Type 2 resumes with required certificates is 14.8 percent, only 3.9 percentage points greater than the rate for Type 2 resumes sent to jobs not requiring additional certificates. The callback rate for Type 4 resumes with required certificates is lower than the callback rate for jobs not listing these additional requirements.

Columns 3 to 5 in Table 10 show the impact from randomly assigning certificates to resumes for jobs that mention these certificates are preferred. Column 3 shows callback differences by resume type for this small sub-sample. Column 4 shows 
coefficient estimates from regressing callback status on resume type, plus an indicator for the resumes assigned the additional certificate. The certificate boosts the chances of a callback by 6.8 percentage points, but the estimate is imprecise and insignificant. Interacting the indicator for including the certificate with resume type generates similar (but imprecise) conclusions as those drawn from the results using resumes with required certificates; the likelihood of hearing back from an employer increases mostly for Type 0 resumes. Overall, obtaining additional Canadian education credentials appears to do little to offset lower callback rates from listing foreign education or experience.

The next table looks at whether callback differences depend on whether the evaluator's gender or ethnicity. For the sets of four resumes sent to an employer that generated at least one callback, I recorded the gender of the person who called back or emailed. I also recorded whether the person spoke with an Asian, Indian, or other ethnic accent, or had an ethnic-sounding name. If the person who contacted an applicant is the same one who considered all four resumes, we can use this information to determine whether callback differences depend on these evaluator characteristics. Table 11 reports similar callback differences whether the evaluator is male or female. Among the set of resumes receiving at least one callback, male evaluators are 82 percent more likely to contact Type 0 resumes over resumes with foreign-sounding names $(0.646 /(1-0.646)$, from Column 2). Females are 86 percent more likely to contact Type 0 resumes. Evaluators with Asian or Indian backgrounds are more likely to call back resumes Asian or Indian names, but still favor resumes with English sounding names by a factor of 1.42. Similarly, evaluators with no accent or ethnic name are about twice as likely to call back a resume with an English-sounding name over a foreign one, while evaluators with an 
ethnic accent or name are still 67 percent more likely to call back a resume with an English-sounding name. The confidence intervals around these estimates, however, are generally too large to draw precise conclusions.

The final table shows how callback rates differ after separating the sample by jobs applied that require above or below median language and social skills. The idea is to explore whether employers trying to hire in jobs that require more intensive language or social skills are even less likely to interview immigrants out of concern they have fewer of these skills than natives. I match each posting's job description with measures of speaking, writing, and social skill using the Occupational Network Database $\left(\mathrm{O}^{*} \mathrm{NET}\right)$. For example the $\mathrm{O}$ *NET records computing programmers as having a score of score 56 (out of 100) under speaking requirements, which is below the median, while receptionists score 79 , which is above the median. The table shows differences in callback rates between Type 0 and Type 1 resumes (that differ by name ethnicity) by skill quartile. Column 1 in the first panel, for example, shows the callback differences for the sample of resumes sent to jobs in the lowest quartile of the O*NET's measure speaking skill requirements. The three most frequent occupations in this category are Accountants, Computer Programmers, and Web Developers. Column 4 in the first panel shows the differences among resumes sent to jobs with speaking skill requirements in the top quartile. These include Receptionists, Sales Representatives, and Financial Managers.

The results hint that employers discriminate more for some jobs with higher speaking and writing skill requirements, but the callback differences overall are quite similar across these skill quartiles. Except for differences among resumes in the lowest speaking skill quartile, the callback ratio between resumes with English-sounding names 
to those with Indian, Chinese, or Pakistani names ranges from 1.3 to 1.9 , with no particular relationship with the O*NET skill measures. If resumes for accounting positions are dropped from the lower quartile sample of speaking and writing skills (because accounts may, in fact, use these skills when interacting with clients), the call back differences change to $0.016($ s.e. $=0.032)$ and $-0.037($ s.e. $=0.024)$ respectively. Perhaps this implies that employers do not particularly discriminate by name ethnicity for jobs such as computer programmers and web developers. Overall, however, the finding of significantly lower callback rates for resumes with foreign names occurs over occupations requiring very different language and social skill requirements.

\section{Discussion and Conclusion}

In this paper, I conduct an audit-study to explore why immigrants, allowed into Canada based on skill, fair so poorly in the labor market. The study's methodology involves sending mock resumes in response to thousands of job postings across a wide set of occupations and industries around the Greater Toronto Area. Multiple resume characteristics are randomized, including name (English, Chinese, Indian, and Pakistani), education (local or foreign university, prestige, and additional credentials), experience, fluency in French, and extra curricular activities. This design leads to knowing exactly what information employers have available when making interview decisions, and allows us to determine what specific characteristics cause callback rates to differ. 
The study leads to three main conclusions. First, Canadian-born individuals with English-sounding names are much more likely to receive a callback for an job interview after sending their resumes compared to foreign-born individuals, even among those with foreign degrees from highly ranked schools, or among those with the same listed job experience but acquired outside of Canada. More specifically, the study finds that 16 percent of resumes sent with English-sounding names, Canadian education and experience received a call back from an employer, compared to only 5 percent for resumes with foreign-sounding names from China, India, or Pakistan, and foreign experience and education. The callback gap lines up with overall unemployment differences- in 2006, for example, the national unemployment rate for immigrants was 11.5 percent, more than double the rate of 4.9 percent for the Canadian-born population (Statistics Canada, 2007). Much of the unemployment difference may therefore be due to immigrants not even making it to the interview stage in the job application process.

The second conclusion is that employers value Canadian experience far more than Canadian education when deciding to interview applicants with foreign backgrounds. Among resumes with foreign names and foreign education, the callback rate climbs from 5 percent to 8 percent by listing just one previous job with a company located inside Canada rather than outside. Listing all job experience with companies located inside Canada leads to the callback rate increasing further to 11 percent. These substantial increases are noteworthy especially in light of the fact that only job location differs while keeping constant job descriptions and company names (e.g. ABC Inc., Toronto versus ABC Inc., Beijing). Employers are much more interested in foreign-born applicants with more Canadian experience. Letting in more of these immigrants, or helping recent 
arrivals find initial work that matches their previous background may help to boost immigrants' wage trajectories.

While Canadian experience plays a crucial role in determining the likelihood of a callback, having a degree from a more prestigious foreign institution, or acquiring additional schooling in Canada does not appear impact the chances of a callback significantly. Conditional on listing 4 to 6 years of Canadian experience on a resume, callback rates do not differ significantly by whether a resume lists a Bachelor's degree from nearby Canadian university or lists one from a foreign university. I also find little effect from indicating an applicant graduated from a top ranking school compared to a low-ranking one, even among resumes with degrees from Canadian institutions. This surprises me, since admission criteria varies widely by school. It may indicate employers do not pay close attention to education qualifications for resumes with several years of experience. The one exception is Canadian resumes with foreign names. While there is no effect for similar applicants with English names, applicants with foreign names receive about 40 percent more callbacks if they list a higher ranked Canadian university. Including credentials listed as required or desired for a job naturally raises callback rates, but more so for native resumes with English names than for immigrant resumes with foreign names. ${ }^{19}$ I find no effect from listing an additional Canadian Master's degree. Recruiters I discussed these results with are not surprised; all said that education plays only a minor role in deciding whether to call back for an interview once an applicant has accumulated 4 to 6 years of experience.

\footnotetext{
19 These results are similar to Ferrer and Riddell (2004), and do not support Dietz and Esses's (2007) conclusion that standardizing native and immigrant education credentials would equalize employer interest.
} 
The third conclusion is that employers discriminate substantially by the name. More specifically, employer contact falls 40 percent when switching from a Canadian resume with a common English name to one with a common Indian, Chinese, or Pakistani name (16 percent to 11 percent respectively). This difference is substantial, and almost as large as that found by Bertrand and Mullainathan (2003) using resumes in the United States with Black or White sounding names.

A potential explanation for these different callback rates is that employers statistically discriminate by name and location of experience because they believe these characteristics signal a greater chance of inadequate language and cultural skills for the job. The finding that callback differences vanish when comparing Canadian resumes with British resumes suggests that this may be the case, since British immigrants arrive fluent in English and with similar cultural background to those from Canada. Other evidence, however, suggests that this is not the full story. Foreign-named applicants with Canadian experience and education are more likely second-generation immigrants than first, especially when only the last name sounds foreign (e.g. Amy Wang). Employers should not expect these applicants to face significant language or social difficulties, yet callback differences between them and resumes with all English-sounding names remain.

Another reason to believe statistical discrimination based on language and social skill concerns cannot fully explain the results is that I find similar callback differences by name whether comparing resumes sent to jobs requiring extensive communication skills to resumes that don't. We would expect that if discrimination occurs primarily because employers believe ethnic applicants might lack adequate communication skills to see larger differences in callback rates among ethnic and non-ethnic resumes sent in response 
to jobs that require more of these skills. As further evidence against the statistical discrimination story, I also find no difference in callback rates between immigrant or non-immigrant resumes listing fluency in French and other languages. My initial conjecture was that, if employers are concerned about candidates lacking communication skills, explicitly indicating multiple language fluency on the resume should mitigate these concerns.

Another possibility behind the results is that employers prefer to hire individuals of similar ethnic or language backgrounds (this behavior is sometimes referred to as taste-based discrimination). I report evidence, however, to suggest that this type of discrimination also cannot fully explain the findings. For example, recruiting agencies are slightly less likely to respond to resumes with ethnic names compared with employers that sort through resumes themselves. Since agencies do not have to interact with individuals that get the job, they should not care about ethnicity as much as employers when deciding who to interview. I also find that evaluators with Asian or Indian accents or names are less likely to callback resumes with Asian or Indian names (although these results are somewhat imprecise). This finding also goes counter to the taste-based discrimination hypothesis.

Regardless of what behavior underlies these results, deciding whether to interview an applicant based solely on his or her name is illegal under the Ontario Human Rights Act. $^{20}$ This behavior leads to applicants not being given a chance to show employers that

\footnotetext{
20 The Human Rights Act in Ontario states, "Every person has a right to equal treatment with respect to employment without discrimination because of race, ancestry, place of origin, colour, ethnic origin, citiznship, creed, sex, sexual orientation, age, record of offences, marital status, family status or disability". R.S.O. 1990, c.H.19,s.5(1); 1999,c.6, s. 28 (5); 2001, c. 32, s. 27 (1); 2005, c. 5, s. 32 (5). An
} 
underlying concerns about inadequate skills are unjustified. Previous research on why immigrants do not assimilate in the labor market has largely ignored this potential explanation, perhaps because of lack of data. My study, in contrast, suggests discrimination (regardless of what kind of discrimination) could be a leading explanatory factor. Discrimination causes immigrants to miss out on hiring opportunities in situations where they are most qualified for a job. Employers may miss out too, by hiring less qualified workers. The costs to employers from not interviewing an immigrant, however, are likely not as large as the costs to immigrants from not being selected. Screeners typically must sort through hundreds of resumes to identify a handful of candidates to interview. The process involves considerable ambiguity: in the search for a "good" job applicant, there is no such thing as a simple formula to be followed to determine which candidates are above the bar. The chance that a marginal candidate not picked would have been hired and would have significantly outperformed the next best candidate is probably small.

A number of researchers suggest that the conditions by which employers sort through resumes make it more likely that name discrimination is unintentional (Stanley Phelps, and Banaji, 2008). Social psychologists differentiate between explicit attitudes, which describe one's expressed views, and implicit attitudes, which are unconscious mental associations between a target (such as immigrants) and a given attribute (such as "poor communication skills"). Implicit attitudes may operate subconsciously, and cause people to make decisions in ways that oppose their own conscious and deliberative views

employee with the Ontario Human Rights Commission also confirmed the illegality of name-based discrimination, but said that she was not aware of any case that had been brought to the Commission's attention. 
(Ranganath, Smith, and Nosek, 2006). Chugh (2004) argues that time pressure, stress, and ambiguity in whether to place resumes on the "yes" pile or the "no" pile all make it more likely that employers use automatic implicit attitudes to decide.

Implicit attitudes can be measured. The Implicit Association Test (IAT) (Greenwald et al., 1998) relies on test takers' speed of response to represent the strength of their unconscious mental associations. ${ }^{21}$ Rooth (2009) matches self-reported racial attitudes and IAT scores of employers to callback outcomes from an audit study he carried out that looks at discrimination between resumes with common Swedish names and Arab-Muslim names. Those with more negative implicit association measures are less likely to callback Arab-Muslims, while self-reported measures of explicit association have little explanatory power. Bertrand, Chugh, and Mullainathan (2005) report similar results from a study involving picking qualified candidates from a set of resumes with White and African-American names. They find a negative correlation between the number of African-American resumes selected by a given subject and that subject's IAT score. The correlation is largest among those subjects that report feeling most rushed during the task. They also find no correlation between the number of African-American resumes picked and self-reported explicit attitudes towards African Americans. Those surveyed, however, may find it easier to mask or not admit their explicit attitudes, which may explain why these explicit measures do not correlate with implicit measures.

If discrimination is unintentional, then employers gain from realizing they do it. Correcting accidental tendencies of favoring native Caucasian candidates may lead to better hires. Ethnic applicants, of course, also gain. We should therefore add this

\footnotetext{
${ }^{21}$ Readers can take the test for themselves online: (http://implicit.harvard.edu).
} 
explanation to the list of candidates to explain the substantial wage and employment gap between recent skilled immigrants and natives. Further research is needed to investigate exactly why employers are much less interested in interviewing candidates with foreignsounding names. 


\section{References}

Antecol, H., Peter Kuhn, and S.J. Trejo. 2003. "Assimilation via prices or quantities? Labor market institutions and immigrant earnings growth in Austrailia, Canada, and the United States," No. 802, Institute for the Study of Labour (IZA) Discussion Paper.

Aydemir, Abdurrahman and Mikal Skuterud. 2004. "Explaining the Deteriorating Entry Earnings of Canada's Immigrant Cohorts: 1966-2000.” Analytical Studies Research Paper Series. Catalogue No. 11F0019MIE2004225. Ottawa: Statistics Canada.

Beach, Charles, Alang G. Green, and Christopher Worswick, "Impacts of the Point System and Immigration Policy Levers on Skill Characteristics of Canadian Immigrants," Queens Economics Department WORKING paper No. 1115, 2006.

Bertrand, Marianne and Sendhil Mullainathan, 2004. "Are Emily and Greg More Employable than Lakisha and Jamal? A Field Experiment on Labor Market Discrimination," American Economic Review, American Economic Association, vol. 94(4), pages 991-1013, September.

Bertrand, M., D. Chugh, and S. Mullainathan (2005). "New approaches to Discrimination Implicit Discrimination," American Economic Review Papers and Proceedings, 95(2), 94-98.

Borjas, G.J. (1993) "Immigration Policy, National Origin and Immigrant Skills: A Comparison of Canada and the United States," in Small Differences That Matter: Labor Markets and Income Maintenance in Canada and the United States, David Card and Richard Freeman (eds), Chicago: University of Chicago Press. Pp. 21-43

Carlsson, Magnus, and Dan-Olof Rooth. (2007). "Evidence of Ethnic Discrimination in the Swedish Labor Mart," Labour Economics Vol. 14, pp. 716-729

Dietz, Joerg, and Victoria Esses (2007). “The evaluation of immigrants' credentials: The roles of accreditation, immigrant race, and evaluator biases," CLSRN Working Paper Number 30.

Dolan, Benjamin, and Margaret Young (2004). "Canada's Immigration Program," Parliamentary Information and Research Service Background Paper BP-190E.

Ferrer, A. and Craig Riddell. (2008). "Education, Credentials, and Immigrant Earnings," Canadian Journal of Economics, Vol. 40, No. 1.

Fix, M. and R.J. Struyk (1993). "Clear and Convincing Evidence: Measurement of Discrimination in America. Washington D.C., Urban Institute Press, distributed by University Press of America Lanham Md. 
Frenette, Marc and René Morissette. 2005. "Will they ever converge? Earnings of immigrant and Canadian-born workers over the last two decades," International Migration Review, Vol. 39, No. 1 (Spring 2005), pp 228-258.

Green, David A. and Christopher Worswick. 2002. "Earnings of Immigrant Men in Canada: The Roles of Labour Market Entry Effects and Returns to Foreign Experience.". University of British Columbia, Department of Economics. Paper prepared for Citizenship and Immigration Canada.

Henry, Frances, and Effie Ginzberg, "Who gets the work? A test of racial discrimination in employment," The Urban Alliance on Race Relations and the Social Planning Council of Metropolitan Toronto, January 1985.

Lahey, Joanna,Age, Women, and Hiring: An Experimental Study. Journal of Human Resources, Vol. 18, No. 1, 2008.

Lahey, Joanna and Beasley, Ryan A., "Computerizing Audit Studies" (July 1, 2007). Available at SSRN: http://ssrn.com/abstract $=1001038$

Lalonde, R. J. and R.H. Topel (1992) "The Assimilation of Immigrants in the U.S. Labor Market," in Immigration and the Work Force, G.J. Borjas and R.B. Freeman (eds), Chicago: The University of Chicago Press. Pp. 67-92

Li, Peter S. 2003. "Initial Earnings and Catch-up Capacity of Immigrants." Canadian Public Policy. XXIX(3): 319-327.

Lubotsky, Darren. "Chutes or Ladders? A Longitudinal Analysis of Immigrant Earnings," Journal of Political Economy, 2007, vol. 115, no. 5. Pp. 820-867

Picot, Garnett, and Arthur Sweetman, "The Deteriorating Economic Welfare of Immigrants and Possible Causes: Update 2005," Statistics Canada Analytical Studies Branch Research Paper \#262, 2005.

Riach, P.A., and J. Rich, "Field experiments of discrimination in the market place," The Economic Journal, Vol. 112 (Noember), 2002, pp. F480-F518.

Reitz, Jeffrey. 2001. "Immigrant success in the knowledge economy: institutional changes and

the immigrant experience in Canada, 1970-1995." Journal of Social Issue. 57: 579613.

Rooth, Dan-Olof (2009). "Automaatic Associations and Discrimination in Hiring Real World Evidence," Mimeo.

Schaafsma, J. and A. Sweetman. 2001. "Immigrant Earnings: age at immigration matters." Canadian Journal of Economics. 34(4): 1066-1099. 
Statistics Canada. (2007). "The Canadian Immigrant Labour Market in 2006: First Results from Canada's Labour Force Survey," Catalogue no. 71-606-XIE

Statistics Canada. (2008). "Earnings and Incomes of Canadians Over the Past Quarter Century," Catalogue no. 97-563-X

Worswick, Christopher (2004). "Immigrants' Declining Earnings: Reasons and Remedies,” C.D. Howe Institute Backgrounder, No. 81, April 2004. 
Table 1

Unemployment and Earnings Differences Between Recent Immigrants and Natives Aged 25 to 39 From the 2001 Census

\begin{tabular}{|c|c|c|c|}
\hline & (1) & (2) & (3) \\
\hline & $\begin{array}{l}\text { Unemployment } \\
\text { Rate }\end{array}$ & $\begin{array}{l}\text { Mean Earnings } \\
\text { for Positive Earners } \\
\text { in Labor Force }\end{array}$ & $\begin{array}{l}\text { Median Earnings } \\
\text { for Positive Earners } \\
\text { in Labor Force }\end{array}$ \\
\hline Non-Immigrants & 0.069 & 33177 & 30000 \\
\hline Recent Immigrants (0-4 years) & 0.134 & 25694 & 20181 \\
\hline Ratio (Non-Immig / Immig) & 0.51 & 1.29 & 1.49 \\
\hline $\begin{array}{l}\text { Estimated Ratio, conditional } \\
\text { on age, schooling, and city }\end{array}$ & 0.43 & 1.52 & 1.81 \\
\hline Sample Size & 128890 & 109625 & 109625 \\
\hline
\end{tabular}

Notes: The sample in Column 1 includes all individuals from the 2001 Public-Use Canadian Census, aged 25 to 39, in the labor force, and either recorded as a non-immigrant, or a recent immigrant (arrived within the last 5 years). The sample in Columns 2 and 3 is restricted further to individuals with positive earnings. All amounts are in 2000 Canadian dollars. The estimated ratio is computed by first regressing unemployment status or log earnings on immigrant status, plus fixed effects for age, highest degree, and city of residence. The unemployment rate and mean earnings is imputed using the immigrant coefficient from the regression, relative to the actual value for non-immigrants, and the ratio of this is reported in the table. For column 3 , quantile regregression around the median is used instead of ordinary least squares. 
Table 2

Number of Resumes Sent and Callbacks Received by Resume Type and Ethnicity

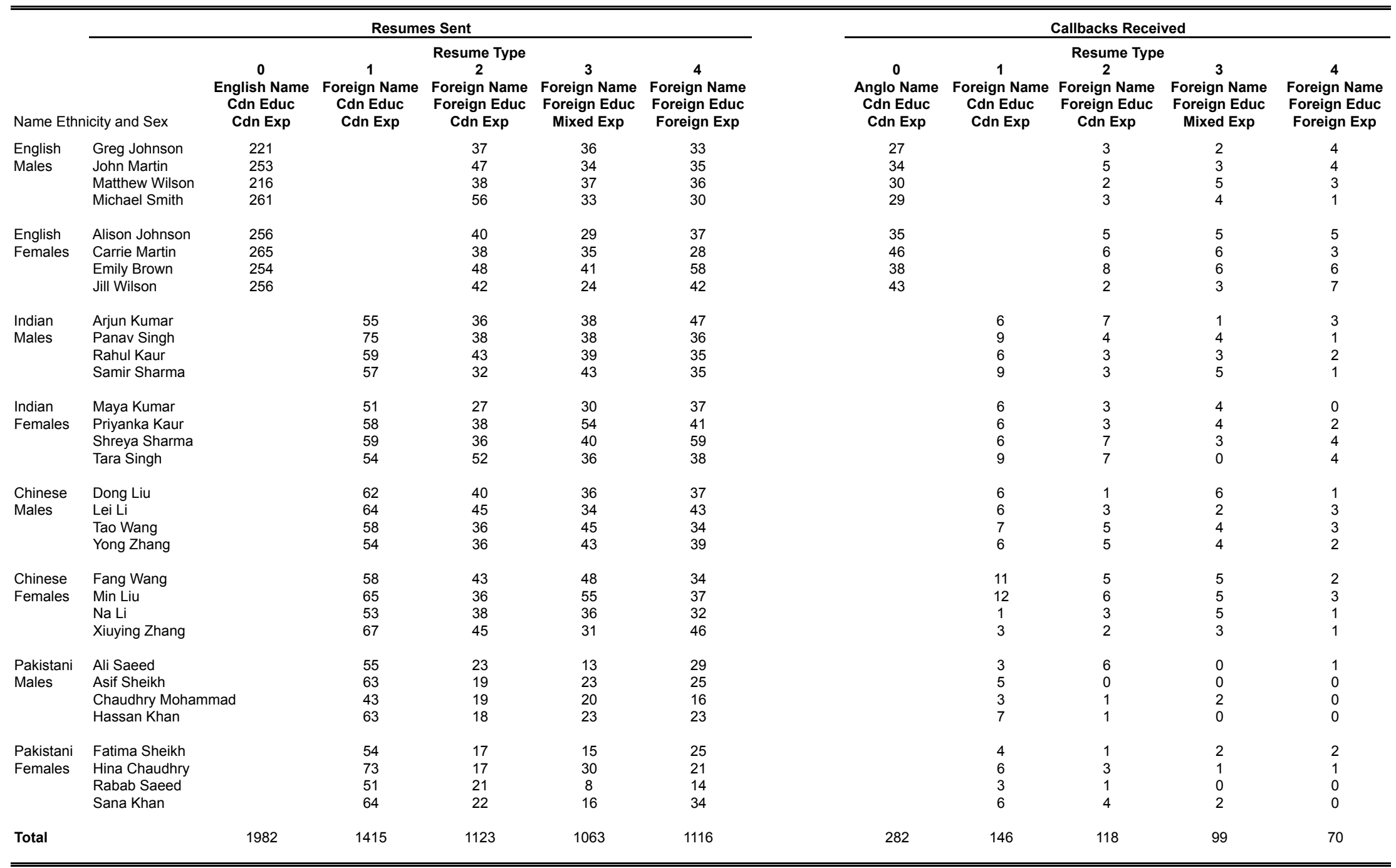

Notes: $\mathrm{Cdn}=$ Canadian, Educ $=$ Country where bachelors degree obtained, and exp = country where job experience obtained. Mixed experience corresponds to first two jobs listed on resume are from foreign country, and most recent (third) job listed is from Canada. 
Table 3

Resume Characteristics, by Resume Type

(1)

\section{Characteristics of Resume}

\begin{tabular}{|c|c|c|c|c|c|c|}
\hline & Full Sample & $\begin{array}{c}0 \\
\text { English Name } \\
\text { Cdn Educ } \\
\text { Cdn Exp }\end{array}$ & $\begin{array}{c}1 \\
\text { Foreign Name } \\
\text { Cdn Educ } \\
\text { Cdn Exp }\end{array}$ & $\begin{array}{l}2 \\
\text { Foreign Name } \\
\text { Foreign Educ } \\
\text { Cdn Exp }\end{array}$ & $\begin{array}{l}3 \\
\text { Foreign Name } \\
\text { Foreign Educ } \\
\text { Mixed Exp }\end{array}$ & $\begin{array}{c}4 \\
\text { Foreign Name } \\
\text { Foreign Educ } \\
\text { Foreign Exp }\end{array}$ \\
\hline Female & 0.51 & 0.52 & 0.50 & 0.50 & 0.50 & 0.52 \\
\hline Top 200 World Ranking University & 0.46 & 0.50 & 0.51 & 0.41 & 0.43 & 0.41 \\
\hline Extra Curricular Activities Listed & 0.61 & 0.60 & 0.60 & 0.60 & 0.61 & 0.63 \\
\hline Fluent in French and other Languages & 0.20 & 0.20 & 0.21 & 0.20 & 0.21 & 0.19 \\
\hline Canadian Masters Degree & 0.16 & 0.20 & 0.19 & 0.20 & 0.20 & 0.00 \\
\hline \multicolumn{7}{|l|}{ Name Ethnicity } \\
\hline Engligh Name & 0.30 & 1.00 & 0.00 & 0.00 & 0.00 & 0.00 \\
\hline Chinese Name & 0.21 & 0.00 & 0.34 & 0.28 & 0.31 & 0.27 \\
\hline Indian Name & 0.21 & 0.00 & 0.33 & 0.27 & 0.30 & 0.29 \\
\hline Pakistani Name & 0.14 & 0.00 & 0.33 & 0.14 & 0.14 & 0.17 \\
\hline \multicolumn{7}{|l|}{ Resume Sent In: } \\
\hline May-08 & 0.05 & 0.04 & 0.05 & 0.04 & 0.05 & 0.05 \\
\hline Jun-08 & 0.34 & 0.29 & 0.40 & 0.33 & 0.37 & 0.34 \\
\hline Jul-08 & 0.15 & 0.13 & 0.18 & 0.15 & 0.16 & 0.15 \\
\hline Aug-08 & 0.03 & 0.03 & 0.04 & 0.03 & 0.03 & 0.03 \\
\hline Sep-08 & 0.15 & 0.21 & 0.10 & 0.16 & 0.14 & 0.14 \\
\hline Oct-08 & 0.23 & 0.26 & 0.19 & 0.24 & 0.20 & 0.24 \\
\hline Nov-08 & 0.05 & 0.06 & 0.04 & 0.05 & 0.05 & 0.05 \\
\hline
\end{tabular}

Notes: Top 200 World Ranking University according to the 2008 QS World Rankings (http://www.topuniversities.com/).

(6)

\section{Resume Type Sent}

(2) (3)

$(4)$ 
Table 4

Callback Rates by Resume Type and Ethnic Origin

\begin{tabular}{|c|c|c|c|c|c|c|c|}
\hline & & (1) & $(2)$ & (3) & (4) & (5) & (6) \\
\hline & & \multicolumn{6}{|c|}{$\begin{array}{c}\text { Callback Rate } \\
\text { (Difference Compared to Type 0) } \\
\text { [Standard Error of Difference] } \\
\text { \{Callback Ratio: Type 0 / Type }\end{array}$} \\
\hline & & \multicolumn{6}{|c|}{ Ethnic Origin } \\
\hline & & English-Canada & India & China & Pakistan & Britain & $\begin{array}{c}\text { India/China/ } \\
\text { Pakistan }\end{array}$ \\
\hline Type 0 & $\begin{array}{l}\text { English Name } \\
\text { Cdn Educ } \\
\text { Cdn Exp }\end{array}$ & 0.158 & & & & & \\
\hline Type 1 & $\begin{array}{l}\text { Foreign Name } \\
\text { Cdn Educ } \\
\text { Cdn Exp }\end{array}$ & & $\begin{array}{c}\mathbf{0 . 1 2 1} \\
(-0.037) \\
{[0.019]^{*}} \\
\{1.31\}\end{array}$ & $\begin{array}{c}\mathbf{0 . 1 0 8} \\
(-0.050) \\
{[0.018]^{* * *}} \\
\{1.46\}\end{array}$ & $\begin{array}{c}0.11 \\
(-0.048) \\
{[0.016]^{* * *}} \\
\{1.44\}\end{array}$ & NA & $\begin{array}{c}\mathbf{0 . 1 1 3} \\
(-0.045) \\
{[0.011]^{* * *}} \\
\{1.40\}\end{array}$ \\
\hline Type 2 & $\begin{array}{l}\text { Foreign Name } \\
\text { Foreign Educ } \\
\text { Cdn Exp }\end{array}$ & & $\begin{array}{c}\mathbf{0 . 1 2 2} \\
(-0.036) \\
{[0.022]} \\
\{1.30\}\end{array}$ & $\begin{array}{c}\mathbf{0 . 0 9 4} \\
(-0.064) \\
{[0.020]^{* * *}} \\
\{1.68\}\end{array}$ & $\begin{array}{c}\mathbf{0 . 1 4} \\
(-0.018) \\
{[0.027]} \\
\{1.13\}\end{array}$ & $\begin{array}{c}\mathbf{0 . 1 2 9} \\
(-0.029) \\
{[0.019]} \\
\{1.22\}\end{array}$ & $\begin{array}{c}\mathbf{0 . 1 1 4} \\
(-0.044) \\
{[0.014]^{* * *}} \\
\{1.39\}\end{array}$ \\
\hline Type 3 & $\begin{array}{l}\text { Foreign Name } \\
\text { Foreign Educ } \\
\text { Mixed Exp }\end{array}$ & & $\begin{array}{c}\mathbf{0 . 0 7 5} \\
(-0.083) \\
{[0.019]^{* * *}} \\
\{2.11\}\end{array}$ & $\begin{array}{c}\mathbf{0 . 1 0 3} \\
(-0.055) \\
{[0.021]^{\star * *}} \\
\{1.53\}\end{array}$ & $\begin{array}{c}\mathbf{0 . 0 7 8} \\
(-0.080) \\
{[0.020]^{\star * *}} \\
\{2.03\}\end{array}$ & $\begin{array}{c}\mathbf{0 . 1 5 7} \\
(-0.001) \\
{[0.023]} \\
\{1.01\}\end{array}$ & $\begin{array}{c}\mathbf{0 . 0 8 8} \\
(-0.070) \\
{[0.013]^{* * *}} \\
\{1.80\}\end{array}$ \\
\hline Type 4 & $\begin{array}{l}\text { Foreign Name } \\
\text { Foreign Educ } \\
\text { Foreign Exp }\end{array}$ & & $\begin{array}{c}\mathbf{0 . 0 5 1} \\
(-0.107) \\
{[0.017]^{* * *}} \\
\{3.10\}\end{array}$ & $\begin{array}{c}\mathbf{0 . 0 5 3} \\
(-0.105) \\
{[0.018]^{\star * *}} \\
\{2.98\}\end{array}$ & $\begin{array}{c}\mathbf{0 . 0 5 2} \\
(-0.106) \\
{[0.015]^{\star * *}} \\
\{3.04\}\end{array}$ & $\begin{array}{c}\mathbf{0 . 1 4 1} \\
(-0.017) \\
{[0.021]} \\
\{1.12\}\end{array}$ & $\begin{array}{c}\mathbf{0 . 0 5 2} \\
(-0.106) \\
{[0.011]^{* * *}} \\
\{3.04\}\end{array}$ \\
\hline
\end{tabular}

Notes: Cdn = Canadian, Educ = Country where bachelors degree obtained, and exp = country where job experience obtained. Mixed experience corresponds to first two jobs listed on resume are from foreign country, and most recent (third) job listed is from Canada. $* * *$, $* *$, and * indicate callback rate differences compared to Type 0 are statistically significant at the $1 \%, 5 \%$, and $10 \%$ levels respectively. 
Table 5

Estimated Callback Rate Differences by Resume Type, Conditional on Other Resume Characteristics and Employer Fixed Effects

\begin{tabular}{|c|c|c|c|c|c|}
\hline & & (1) & $(2)$ & (3) & $(4)$ \\
\hline & & \multicolumn{4}{|c|}{ Dependent Variable: Callback } \\
\hline $\begin{array}{l}\text { Constant } \\
\text { (Type } 0 \text { Callback Rate } \\
\text { When Other Control Variables }=0 \text { ) }\end{array}$ & $\begin{array}{l}\text { English Name } \\
\text { Cdn Educ } \\
\text { Cdn Exp }\end{array}$ & $\begin{array}{c}0.158 \\
{[0.009]^{\star * *}}\end{array}$ & $\begin{array}{c}0.148 \\
{[0.006]^{\star * *}}\end{array}$ & $\begin{array}{c}0.164 \\
{[0.022]^{* * *}}\end{array}$ & $\begin{array}{c}0.143 \\
{[0.010]^{\star * *}}\end{array}$ \\
\hline $\begin{array}{l}\text { Type } 1 \\
\text { (Callback rate difference btw. Type } 0 \\
\text { Holding Control Variables Constant) }\end{array}$ & $\begin{array}{l}\text { Foreign Name } \\
\text { Cdn Educ } \\
\text { Cdn Exp }\end{array}$ & $\begin{array}{c}-0.045 \\
{[0.011]^{\star \star *}}\end{array}$ & $\begin{array}{c}-0.047 \\
{[0.009]^{\star \star *}}\end{array}$ & $\begin{array}{c}-0.044 \\
{[0.011]^{\star * *}}\end{array}$ & $\begin{array}{c}-0.047 \\
{[0.009]^{\star * *}}\end{array}$ \\
\hline $\begin{array}{l}\text { Type } 2 \\
\text { (Callback rate difference btw. Type } 0 \\
\text { Holding Control Variables Constant) }\end{array}$ & $\begin{array}{l}\text { Foreign Name } \\
\text { Foreign Educ } \\
\text { Cdn Exp }\end{array}$ & $\begin{array}{c}-0.044 \\
{[0.014]^{\star * *}}\end{array}$ & $\begin{array}{c}-0.047 \\
{[0.011]^{\star * *}}\end{array}$ & $\begin{array}{c}-0.042 \\
{[0.014]^{\star * *}}\end{array}$ & $\begin{array}{c}-0.046 \\
{[0.011]^{\star * *}}\end{array}$ \\
\hline $\begin{array}{l}\text { Type } 3 \\
\text { (Callback rate difference btw. Type } 0 \\
\text { Holding Control Variables Constant) }\end{array}$ & $\begin{array}{l}\text { Foreign Name } \\
\text { Foreign Educ } \\
\text { Mixed Exp }\end{array}$ & $\begin{array}{c}-0.07 \\
{[0.013]^{\star * *}}\end{array}$ & $\begin{array}{c}-0.06 \\
{[0.011]^{\star * *}}\end{array}$ & $\begin{array}{c}-0.068 \\
{[0.013]^{\star * *}}\end{array}$ & $\begin{array}{c}-0.06 \\
{[0.011]^{\star * *}}\end{array}$ \\
\hline $\begin{array}{l}\text { Type } 4 \\
\text { (Callback rate difference btw. Type } 0 \\
\text { Holding Control Variables Constant) }\end{array}$ & $\begin{array}{l}\text { Foreign Name } \\
\text { Foreign Educ } \\
\text { Foreign Exp }\end{array}$ & $\begin{array}{c}-0.106 \\
{[0.011]^{* * *}}\end{array}$ & $\begin{array}{c}-0.108 \\
{[0.011]^{\star * *}}\end{array}$ & $\begin{array}{c}-0.105 \\
{[0.011]^{\star * *}}\end{array}$ & $\begin{array}{c}-0.110 \\
{[0.012]^{\star \star \star}}\end{array}$ \\
\hline Female & & & & $\begin{array}{c}0.015 \\
{[0.008]^{*}}\end{array}$ & $\begin{array}{c}0.010 \\
{[0.008]}\end{array}$ \\
\hline Top 200 World Ranking University & & & & $\begin{array}{c}0.012 \\
{[0.008]}\end{array}$ & $\begin{array}{c}0.000 \\
{[0.008]}\end{array}$ \\
\hline Extra Curricular Activities Listed & & & & $\begin{array}{c}-0.006 \\
{[0.008]}\end{array}$ & $\begin{array}{c}0.000 \\
{[0.007]}\end{array}$ \\
\hline Fluent in French and other Languages & & & & $\begin{array}{c}-0.004 \\
{[0.010]}\end{array}$ & $\begin{array}{c}0.000 \\
{[0.009]}\end{array}$ \\
\hline Canadian Masters Degree & & & & $\begin{array}{c}-0.007 \\
{[0.011]}\end{array}$ & $\begin{array}{l}-0.007 \\
{[0.011]}\end{array}$ \\
\hline Job Fixed Effects? & & No & Yes & No & Yes \\
\hline Sample Size & & 5785 & 5785 & 5785 & 5785 \\
\hline
\end{tabular}

Notes: The table reports coefficient results from regressing callback status ( 0 or 1 ) on resume type, with Type 0 omitted from the regression. Robust standard errors are reported. Job fixed effects are a set of dummy variables for each separate job posting. Columns 3 and 4 include additional controls for sex, an indicator that the applicant obtained her bachelors degree from a university ranked in the top 200 according to the QS University World Rankings, and indicator for whether the resume mentions fluency in English, mother tongue (if applicable), and French, and a indicator for whether a Canadian Masters Degree was obtained. Cdn = Canadian, Educ = Country where bachelors degree obtained, and exp = country where job experience obtained. Mixed experience corresponds to first two jobs listed on resume are from foreign country, and most recent (third) job listed is from Canada. $* * *, * *$, and $*$ indicate callback rate differences compared to Type 0 are statistically significant at the $1 \%$, $5 \%$, and $10 \%$ levels respectively. 
Table 6

Estimated Callback Effects from Resume Characteristics, by Resume Type

\begin{tabular}{|c|c|c|c|c|c|c|}
\hline & $\begin{array}{c}\text { (1) } \\
\text { Full Sample }\end{array}$ & $\begin{array}{c}(2) \\
\text { Type } 0 \\
\text { English Name } \\
\text { Cdn Educ } \\
\text { Cdn Exp }\end{array}$ & $\begin{array}{c}(3) \\
\text { Type } 1 \\
\text { Foreign Name } \\
\text { Cdn Educ } \\
\text { Cdn Exp }\end{array}$ & $\begin{array}{c}\text { (4) } \\
\text { Type } 2 \\
\text { Foreign Name } \\
\text { Foreign Educ } \\
\text { Cdn Exp }\end{array}$ & $\begin{array}{c}\qquad(5) \\
\text { Type } 3 \\
\text { Foreign Name } \\
\text { Foreign Educ } \\
\text { Mixed Exp }\end{array}$ & $\begin{array}{c}\qquad 6) \\
\text { Type } 4 \\
\text { Foreign Name } \\
\text { Foreign Educ } \\
\text { Foreign Exp }\end{array}$ \\
\hline Resume Characteristic & \multicolumn{6}{|c|}{ Dependent Variable: Callback } \\
\hline Female & $\begin{array}{c}0.016 \\
{[0.008]^{* *}}\end{array}$ & $\begin{array}{c}0.033 \\
{[0.016]^{\star *}}\end{array}$ & $\begin{array}{c}0.000 \\
{[0.016]}\end{array}$ & $\begin{array}{c}0.018 \\
{[0.022]}\end{array}$ & $\begin{array}{c}0.012 \\
{[0.020]}\end{array}$ & $\begin{array}{c}0.006 \\
{[0.014]}\end{array}$ \\
\hline Top 200 World Ranking University & $\begin{array}{c}0.02 \\
{[0.008]^{* *}}\end{array}$ & $\begin{array}{c}-0.011 \\
{[0.016]}\end{array}$ & $\begin{array}{c}0.044 \\
{[0.016]^{\star * *}}\end{array}$ & $\begin{array}{c}0.04 \\
{[0.025]}\end{array}$ & $\begin{array}{l}-0.005 \\
{[0.023]}\end{array}$ & $\begin{array}{c}0.008 \\
{[0.018]}\end{array}$ \\
\hline Extra Curricular Activities Listed & $\begin{array}{l}-0.008 \\
{[0.008]}\end{array}$ & $\begin{array}{l}-0.011 \\
{[0.016]}\end{array}$ & $\begin{array}{c}0.001 \\
{[0.016]}\end{array}$ & $\begin{array}{l}-0.029 \\
{[0.024]}\end{array}$ & $\begin{array}{l}-0.001 \\
{[0.020]}\end{array}$ & $\begin{array}{c}0.002 \\
{[0.015]}\end{array}$ \\
\hline Fluent in French and other Languages & $\begin{array}{l}-0.004 \\
{[0.010]}\end{array}$ & $\begin{array}{l}-0.016 \\
{[0.019]}\end{array}$ & $\begin{array}{l}-0.008 \\
{[0.020]}\end{array}$ & $\begin{array}{c}0.054 \\
{[0.031]^{\star}}\end{array}$ & $\begin{array}{l}-0.033 \\
{[0.022]}\end{array}$ & $\begin{array}{c}0.015 \\
{[0.020]}\end{array}$ \\
\hline Canadian Masters Degree & $\begin{array}{c}0.005 \\
{[0.011]}\end{array}$ & $\begin{array}{l}-0.003 \\
{[0.019]}\end{array}$ & $\begin{array}{l}-0.005 \\
{[0.020]}\end{array}$ & $\begin{array}{c}-0.051 \\
{[0.025]^{* *}}\end{array}$ & $\begin{array}{c}0.021 \\
{[0.026]}\end{array}$ & NA \\
\hline Sample Size & 5785 & 1982 & 1415 & 777 & 794 & 817 \\
\hline
\end{tabular}

Notes: The table reports coefficient results from regressing callback status ( 0 or 1 ) on sex, an indicator that the applicant obtained her bachelors degree from a university ranked in the top 200 according to the QS University World Rankings, and indicator for whether the resume mentions fluency in English, mother tongue (if applicable), and French, and a indicator for whether a Canadian Masters Degree was obtained. Robust standard errors are reported. Cdn $=$ Canadian, Educ $=$ Country where bachelors degree obtained, and exp = country where job experience obtained. Mixed experience corresponds to first two jobs listed on resume are from foreign country, and most recent (third) job listed is from Canada. $* * *, * *$, and * indicate callback rate differences compared to Type 0 are statistically significant at the $1 \%, 5 \%$, and $10 \%$ levels respectively. 
Table 7

Estimated Callback Rate Differences by Resume Type and Occupation

\begin{tabular}{|c|c|c|c|c|c|c|c|c|}
\hline & & (1) & $(2)$ & (3) & (4) & $(5)$ & (6) & (7) \\
\hline & & \multicolumn{7}{|c|}{ Occupation Type } \\
\hline Resume Type & & All & Administrative & Finance & $\begin{array}{l}\text { Marketing } \\
\text { \& Sales }\end{array}$ & Programmer & Retail & Other \\
\hline $\begin{array}{l}\text { Type } 0 \\
\text { Callback Rate }\end{array}$ & $\begin{array}{l}\text { English Name } \\
\text { Cdn Educ } \\
\text { Cdn Exp }\end{array}$ & 0.158 & 0.06 & 0.209 & 0.108 & 0.138 & 0.181 & 0.157 \\
\hline $\begin{array}{l}\text { Type } 1 \\
\text { Callback rate difference btw. Type } 0\end{array}$ & $\begin{array}{c}\text { Foreign Name } \\
\text { Cdn Educ } \\
\text { Cdn Exp }\end{array}$ & $\begin{array}{c}-0.045 \\
{[0.011]^{\star \star *}}\end{array}$ & $\begin{array}{l}-0.032 \\
{[0.022]}\end{array}$ & $\begin{array}{l}-0.07 \\
{[0.026]^{* * *}}\end{array}$ & $\begin{array}{l}-0.018 \\
{[0.033]}\end{array}$ & $\begin{array}{l}-0.022 \\
{[0.035]}\end{array}$ & $\begin{array}{c}-0.059 \\
{[0.034]^{*}}\end{array}$ & $\begin{array}{c}-0.05 \\
{[0.021]^{\star *}}\end{array}$ \\
\hline $\begin{array}{l}\text { Type } 2 \\
\text { Callback rate difference btw. Type } 0\end{array}$ & $\begin{array}{c}\text { Foreign Name } \\
\text { Foreign Educ } \\
\text { Cdn Exp }\end{array}$ & $\begin{array}{c}-0.044 \\
{[0.014]^{\star * *}}\end{array}$ & $\begin{array}{c}-0.029 \\
{[0.027]}\end{array}$ & $\begin{array}{c}-0.084 \\
{[0.030]^{* * *}}\end{array}$ & $\begin{array}{c}-0.018 \\
{[0.042]}\end{array}$ & $\begin{array}{l}-0.026 \\
{[0.041]}\end{array}$ & $\begin{array}{c}-0.042 \\
{[0.043]}\end{array}$ & $\begin{array}{c}-0.039 \\
{[0.026]}\end{array}$ \\
\hline $\begin{array}{l}\text { Type } 3 \\
\text { Callback rate difference btw. Type } 0\end{array}$ & $\begin{array}{c}\text { Foreign Name } \\
\text { Foreign Educ } \\
\text { Mixed Exp }\end{array}$ & $\begin{array}{l}-0.07 \\
{[0.013]^{* * *}}\end{array}$ & $\begin{array}{l}-0.012 \\
{[0.029]}\end{array}$ & $\begin{array}{c}-0.105 \\
{[0.029]^{* * *}}\end{array}$ & $\begin{array}{c}-0.064 \\
{[0.037]^{*}}\end{array}$ & $\begin{array}{c}-0.074 \\
{[0.036]^{\star *}}\end{array}$ & $\begin{array}{c}-0.077 \\
{[0.039]^{* *}}\end{array}$ & $\begin{array}{c}-0.067 \\
{[0.023]^{\star * *}}\end{array}$ \\
\hline $\begin{array}{l}\text { Type } 4 \\
\text { Callback rate difference btw. Type } 0\end{array}$ & $\begin{array}{c}\text { Foreign Name } \\
\text { Foreign Educ } \\
\text { Foreign Exp }\end{array}$ & $\begin{array}{c}-0.106 \\
{[0.011]^{\star * *}}\end{array}$ & $\begin{array}{c}-0.059 \\
{[0.019]^{\star * \star}}\end{array}$ & $\begin{array}{c}-0.152 \\
{[0.025]^{\star * *}}\end{array}$ & $\begin{array}{c}-0.078 \\
{[0.031]^{\star *}}\end{array}$ & $\begin{array}{l}-0.044 \\
{[0.039]}\end{array}$ & $\begin{array}{c}-0.106 \\
{[0.035]^{\star \star *}}\end{array}$ & $\begin{array}{c}-0.12 \\
{[0.019]^{\star \star *}}\end{array}$ \\
\hline Sample Size & & 5785 & 705 & 1338 & 661 & 610 & 786 & 1685 \\
\hline
\end{tabular}

Notes: The table reports coefficient results from regressing callback status ( 0 or 1 ) on resume type, with Type 0 omitted from the regression. Robust standard errors are reported. $\mathrm{Cdn}=$ Canadian, Educ $=$ Country where bachelors degree obtained, and exp = country where job experience obtained. Mixed experience corresponds to first two jobs listed on resume are from foreign country, and most recent (third) job listed is from Canada. ***, **, and * indicate callback rate differences compared to Type 0 are statistically significant at the $1 \%, 5 \%$, and $10 \%$ levels respectively. Occupation type indicates the type of experience listed on the resume, customized according to the job description in the job posting. 
Table 8

Estimated Callback Rate Differences by Resume Type and Certificate Requirements (In Addition to Bachelor Degree)

\begin{tabular}{|c|c|c|c|c|c|c|}
\hline & & (1) & (2) & (3) & (4) & (5) \\
\hline Resume Type & & $\begin{array}{l}\text { No Additional } \\
\text { Certificate } \\
\text { Requirement }\end{array}$ & $\begin{array}{l}\text { Must Have Certificate } \\
\text { (Certificate Added } \\
\text { To All Resumes) }\end{array}$ & \multicolumn{3}{|c|}{$\begin{array}{c}\text { Certificate Optional } \\
\text { (Certificatel Asigned Randomly) }\end{array}$} \\
\hline $\begin{array}{l}\text { Type } 0 \\
\text { Callback Rate, } \\
\text { No Credential }\end{array}$ & $\begin{array}{l}\text { English Name } \\
\text { Cdn Educ } \\
\text { Cdn Exp }\end{array}$ & 0.142 & 0.262 & 0.131 & 0.1 & 0.084 \\
\hline Type 1 & $\begin{array}{l}\text { Foreign Name } \\
\text { Cdn Educ } \\
\text { Cdn Exp }\end{array}$ & $\begin{array}{c}-0.039 \\
{[0.012]^{\star \star *}}\end{array}$ & $\begin{array}{c}-0.09 \\
{[0.040]^{\star \star}}\end{array}$ & $\begin{array}{l}-0.037 \\
{[0.063]}\end{array}$ & $\begin{array}{l}-0.031 \\
{[0.063]}\end{array}$ & $\begin{array}{l}-0.031 \\
{[0.068]}\end{array}$ \\
\hline Type 2 & $\begin{array}{l}\text { Foreign Name } \\
\text { Foreign Educ } \\
\text { Cdn Exp }\end{array}$ & $\begin{array}{c}-0.033 \\
{[0.015]^{* \star}}\end{array}$ & $\begin{array}{c}-0.115 \\
{[0.044]^{* * *}}\end{array}$ & $\begin{array}{l}-0.067 \\
{[0.067]}\end{array}$ & $\begin{array}{c}-0.06 \\
{[0.067]}\end{array}$ & $\begin{array}{l}-0.037 \\
{[0.077]}\end{array}$ \\
\hline Type 3 & $\begin{array}{l}\text { Foreign Name } \\
\text { Foreign Educ } \\
\text { Mixed Exp }\end{array}$ & $\begin{array}{l}-0.061 \\
{[0.013]^{\star * *}}\end{array}$ & $\begin{array}{c}-0.152 \\
{[0.043]^{* * *}}\end{array}$ & $\begin{array}{c}0.001 \\
{[0.079]}\end{array}$ & $\begin{array}{c}0.012 \\
{[0.079]}\end{array}$ & $\begin{array}{c}0.011 \\
{[0.086]}\end{array}$ \\
\hline Type 4 & $\begin{array}{l}\text { Foreign Name } \\
\text { Foreign Educ } \\
\text { Foreign Exp }\end{array}$ & $\begin{array}{c}-0.089 \\
{[0.012]^{\star \star \star}}\end{array}$ & $\begin{array}{c}-0.226 \\
{[0.034]^{\star * \star}}\end{array}$ & $\begin{array}{l}-0.073 \\
{[0.064]}\end{array}$ & $\begin{array}{l}-0.064 \\
{[0.063]}\end{array}$ & $\begin{array}{c}0.003 \\
{[0.082]}\end{array}$ \\
\hline Credential & & & & & $\begin{array}{c}0.068 \\
{[0.048]}\end{array}$ & \\
\hline Type 0 * Credential & & & & & & $\begin{array}{c}0.1 \\
{[0.096]}\end{array}$ \\
\hline Type $1{ }^{*}$ Credential & & & & & & $\begin{array}{c}0.011 \\
{[0.138]}\end{array}$ \\
\hline Type $2{ }^{*}$ Credential & & & & & & $\begin{array}{l}-0.054 \\
{[0.148]}\end{array}$ \\
\hline Type 3 * Credential & & & & & & $\begin{array}{c}0.023 \\
{[0.185]}\end{array}$ \\
\hline Type 4 * Credential & & & & & & $\begin{array}{l}-0.191 \\
{[0.113]^{\star}}\end{array}$ \\
\hline Sample Size & & 4849 & 734 & 202 & 202 & 202 \\
\hline
\end{tabular}

Notes: Job postings applied to in the sample in Column 1 did not mention a certificate preference or requirement (other than possibly a Bachelors degree). Job postings applied to in the sample in Column 2 required a particular certificate. Each resume in this sample listed this requirement. Job postings applied to in the sample in Columns 3 to 5 mentioned a certificate preference. One or two certificates were randomly assigned to resumes corresponding to these jobs. The table reports coefficients from regressing callback status (0-1) on resume type. Column 5 includes results from interacting resume type with whether the resume listed the credential. See also notes from Table 9. 
Table 9

Callback Rate Differences for Resume Sets Sent to Same Employer,

by Evaluator Characteristics, Conditional on At Least One Callback

(1) (2)

(5)

\section{Type of Evaluator}

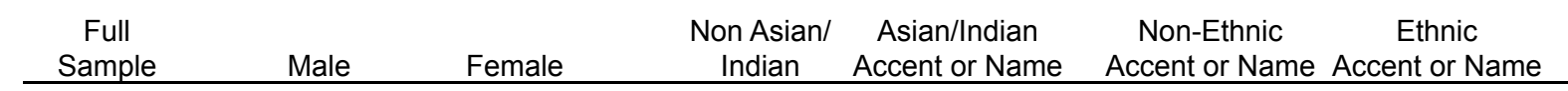

Resume Type

Type 0

Callback Rate

Type 1

Callback rate difference btw. Type 0

Type 2

Callback rate difference btw. Type 0

Type 3

Callback rate difference btw. Type 0

Type 4

Callback rate difference btw. Type 0

English Name
Cdn Educ
Cdn Exp

0.648

0.646

0.65

0.654

0.586

0.665

0.626

Foreign Name
Cdn Educ
Cdn Exp

$-0.193$

$[0.038]^{\star * *}$

$-0.202$

$[0.050]^{\star \star *}$

$-0.178$

$[0.059]^{\star * *}$

$-0.184$

$-0.355$

$[0.160]^{\star *}$

$-0.21$

$[0.048]^{\star \star \star}$

$-0.172$

Foreign Name
Foreign Educ

Cdn Exp

Foreign Name

Foreign Educ

Mixed Exp

Foreign Name

Foreign Educ

Foreign Exp
$-0.222$

$[0.048]^{\star \star *}$

$-0.33$

$[0.064]^{* * *}$

$-0.075$

[0.071]

$-0.236$

$[0.050]^{\star * *}$

$-0.065$

[0.189]

$-0.298$

$[0.065]^{* * *}$

$-0.119$

$-0.291$

$[0.049]^{\star * *}$

$-0.31$

$[0.064]^{\text {*** }}$

$-0.259$

$[0.076]^{\star \star *}$

-0.315
$[0.050]^{* * *}$

0.007

[0.209]

$-0.467$

$[0.057]^{* * *}$

$-0.019$

$-0.49$

$[0.046]^{* * *}$

$-0.502$

$[0.056]^{\star * *}$

$-0.471$

$[0.079]^{\star * *}$

$-0.512$

$[0.047]^{\star * *}$

$-0.244$

[0.197]

$-0.567$

$[0.055]^{* * *}$

$-0.38$
714

494

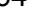

Sample Size

1208

721

487

1114

94

Notes: The table reports coefficient results from regressing callback status ( 0 or 1 ) on resume type, with Type 0 omitted from the regression, and fixed effects for job posting. The sample includes only resumes sets where at least one resume generated a callback. Robust standard errors are reported. Cdn $=$ Canadian, Educ $=$ Country where bachelors degree obtained, and exp = country where job experience obtained. Mixed experience corresponds to first two jobs listed on resume are from foreign country, and most recent (third) job listed is from Canada. $* * *, * *$, and * indicate callback rate differences compared to Type 0 are statistically significant at the $1 \%, 5 \%$, and $10 \%$ levels respectively. 
Table 10

Callback Rate Differences between Resume Types 0 and 1 (name differences), by $O^{*}$ NET Skill Characteristics

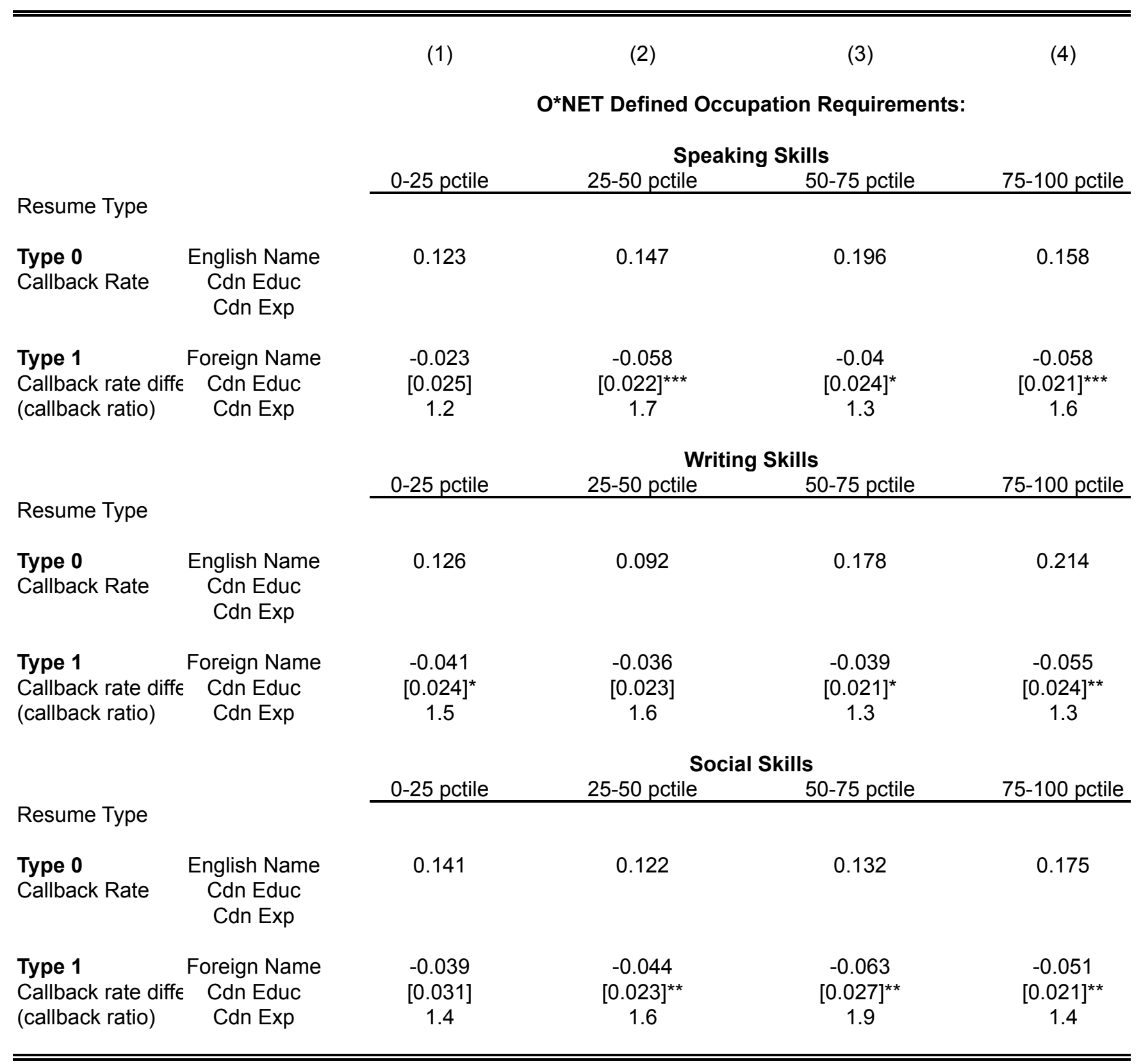

Notes: The table reports coefficient results from regressing callback status ( 0 or 1 ) on resume type, with Type 0 omitted from the regression. The sample is divided into quartiles, based on measures of skill requirements matched to jobs applied using the Occupational Network Database (O*NET). Robust standard errors are reported. $\quad$ Cdn $=$ Canadian, Educ $=$ Country where bachelors degree obtained, and exp = country where job experience obtained. $* * *, * *$, and $*$ indicate callback rate differences compared to Type 0 are statistically significant at the $1 \%, 5 \%$, and $10 \%$ levels respectively. 
Appendix Table 1

Alternative Outcome Measures

\begin{tabular}{|c|c|c|c|c|c|}
\hline & & Callback & $\begin{array}{c}(2) \\
\text { Specific } \\
\text { Interview } \\
\text { Request }\end{array}$ & $\begin{array}{c}\text { (3) } \\
\text { Second } \\
\text { Callback } \\
\end{array}$ & $\begin{array}{c}\text { (4) } \\
\text { Second } \\
\text { Callback } \\
\text { Given First }\end{array}$ \\
\hline \multicolumn{6}{|l|}{ Resume Type } \\
\hline $\begin{array}{l}\text { Type } 0 \\
\text { Callback Rate }\end{array}$ & $\begin{array}{l}\text { English Name } \\
\text { Cdn Educ } \\
\text { Cdn Exp }\end{array}$ & 0.158 & 0.047 & 0.042 & 0.276 \\
\hline $\begin{array}{l}\text { Type } 1 \\
\text { Callback rate difference btw. Type } 0\end{array}$ & $\begin{array}{l}\text { Foreign Name } \\
\text { Cdn Educ } \\
\text { Cdn Exp }\end{array}$ & $\begin{array}{l}-0.045 \\
{[0.011]^{\star * *}}\end{array}$ & $\begin{array}{c}-0.016 \\
{[0.006]^{* *}}\end{array}$ & $\begin{array}{c}-0.014 \\
{[0.006]^{* *}}\end{array}$ & $\begin{array}{l}-0.032 \\
{[0.045]}\end{array}$ \\
\hline $\begin{array}{l}\text { Type } 2 \\
\text { Callback rate difference btw. Type } 0\end{array}$ & $\begin{array}{l}\text { Foreign Name } \\
\text { Foreign Educ } \\
\text { Cdn Exp }\end{array}$ & $\begin{array}{l}-0.044 \\
{[0.014]^{\star * *}}\end{array}$ & $\begin{array}{c}-0.015 \\
{[0.008]^{*}}\end{array}$ & $\begin{array}{c}-0.023 \\
{[0.006]^{* * *}}\end{array}$ & $\begin{array}{c}-0.112 \\
{[0.048]^{\star *}}\end{array}$ \\
\hline $\begin{array}{l}\text { Type } 3 \\
\text { Callback rate difference btw. Type } 0\end{array}$ & $\begin{array}{l}\text { Foreign Name } \\
\text { Foreign Educ } \\
\text { Mixed Exp }\end{array}$ & $\begin{array}{l}-0.07 \\
{[0.013]^{\star * *}}\end{array}$ & $\begin{array}{c}-0.023 \\
{[0.007]^{* * *}}\end{array}$ & $\begin{array}{c}-0.026 \\
{[0.006]^{\star * *}}\end{array}$ & $\begin{array}{c}-0.102 \\
{[0.056]^{*}}\end{array}$ \\
\hline $\begin{array}{l}\text { Type } 4 \\
\text { Callback rate difference btw. Type } 0\end{array}$ & $\begin{array}{l}\text { Foreign Name } \\
\text { Foreign Educ } \\
\text { Foreign Exp }\end{array}$ & $\begin{array}{l}-0.106 \\
{[0.011]^{* * *}}\end{array}$ & $\begin{array}{l}-0.031 \\
{[0.006]^{* * *}}\end{array}$ & $\begin{array}{l}-0.035 \\
{[0.005]^{* * *}}\end{array}$ & $\begin{array}{c}-0.163 \\
{[0.062]^{* * *}}\end{array}$ \\
\hline Sample Size & & 5785 & 5785 & 5785 & 614 \\
\hline
\end{tabular}

Notes: The table reports coefficient results from regressing callback outcomes on resume type, with Type 0 omitted from the regression. Robust standard errors are reported. $C d n=$ Canadian, Educ $=$ Country where bachelors degree obtained, and $\exp =$ country where job experience obtained. Mixed experience corresponds to first two jobs listed on resume are from foreign country, and most recent (third) job listed is from Canada. ${ }^{* * *},{ }^{* *}$, and ${ }^{*}$ indicate callback rate differences compared to Type 0 are statistically significant at the $1 \%, 5 \%$, and $10 \%$ levels respectively. The outcome variable in Column 1 indicates an employer emailed or telephoned to asking to speak with the applicant further. The outcome variable in Column 2 indicates whether the employer specifically mentioned a desire to interview the applicant for the position. The outcome variable in Column 3 indicates whether the employer contacted the applicant more than once. The sample in Column 4 is conditional on the resume receiving an initial callback. 
Appendix Table 2

Callback Rate Differences by Resume Type, using Traditional and Non-Traditional Chinese First Names

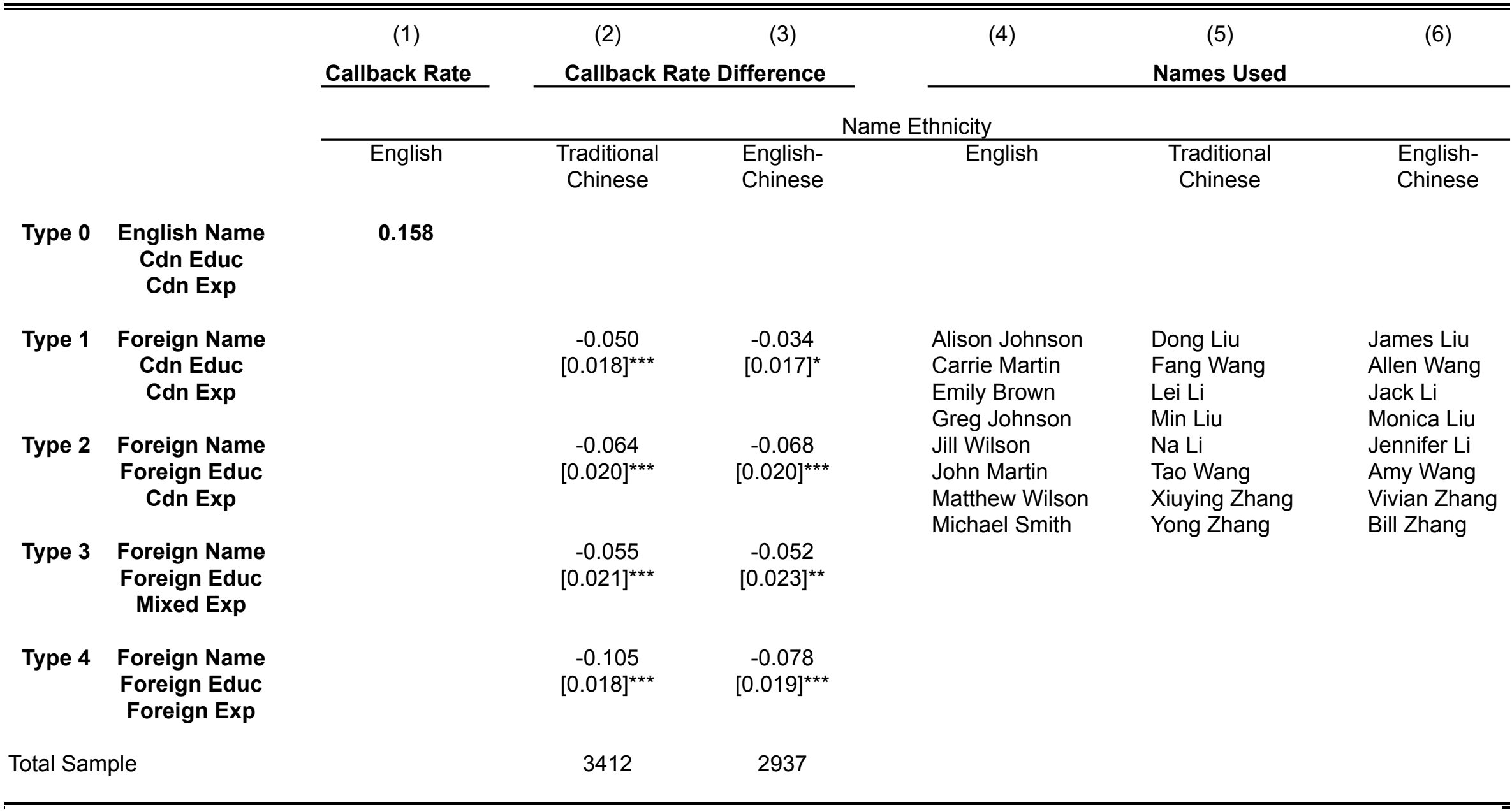

Notes: The table reports coefficient results from regressing callback status on resume type, with Type 0 omitted from the regression. Robust standard errors are reported. $\mathrm{Cdn}=$ Canadian, $\mathrm{Educ}=$ Country where bachelors degree obtained, and exp = country where job experience obtained. Mixed experience corresponds to first two jobs listed on resume are from foreign country, and most recent (third) job listed is from Canada. ${ }^{* * *}$,

$* *$, and $*$ indicate callback rate differences compared to Type 0 are statistically significant at the $1 \%, 5 \%$, and $10 \%$ levels respectively. 
Appendix Table 3

Callback Rates by University

\begin{tabular}{|c|c|c|c|c|c|}
\hline & & (1) & $(2)$ & (3) & (4) \\
\hline Resume Type & & University & Callback Rate & Resumes Sent & $\begin{array}{c}\text { F-Test } \\
\text { (p-value) }\end{array}$ \\
\hline \multirow[t]{6}{*}{ Type 0} & English Name & Brock University & 0.120 & 349 & 0.590 \\
\hline & Cdn Educ & Queen's University* & 0.133 & 323 & \\
\hline & & Ryerson University & 0.165 & 328 & \\
\hline & & University of Toronto* & 0.136 & 339 & \\
\hline & & U oF Toronto at Mississauga & 0.158 & 322 & \\
\hline & & University of Waterloo* & 0.143 & 321 & \\
\hline \multirow[t]{6}{*}{ Type 1} & Foreign Name & Brock University & 0.077 & 235 & 0.082 \\
\hline & Cdn Educ & Queen's University* & 0.128 & 235 & \\
\hline & & Ryerson University & 0.095 & 241 & \\
\hline & & University of Toronto* & 0.112 & 251 & \\
\hline & & Toronto at Mississauga & 0.068 & 219 & \\
\hline & & University of Waterloo* & 0.137 & 234 & \\
\hline \multirow[t]{4}{*}{ Types 2-4 } & Indian Name & Dayalbagh Educational Institute & 0.064 & 251 & 0.432 \\
\hline & Foreign Educ & Indian Institute of Management* & 0.102 & 216 & \\
\hline & & Indian Institute of Technology* & 0.092 & 239 & \\
\hline & & University Of Pune & 0.074 & 242 & \\
\hline \multirow[t]{4}{*}{ Types 2-4 } & Chinese Name & Jinzhong University & 0.057 & 230 & 0.074 \\
\hline & Foreign Educ & Lanzhou University & 0.111 & 262 & \\
\hline & & Peking University* & 0.065 & 245 & \\
\hline & & Tsinghua University* & 0.104 & 212 & \\
\hline \multirow[t]{4}{*}{ Types 2-4 } & Pakistani Name & Hamdard University & 0.076 & 119 & 0.412 \\
\hline & Foreign Educ & Isra University & 0.067 & 135 & \\
\hline & & Quaid-i-Azam University & 0.033 & 123 & \\
\hline & & University of the Punjab & 0.053 & 114 & \\
\hline
\end{tabular}

Notes: Resume types are the same as indicated in Table 6. The F-Test corresponds to the test that all callback rates by university are the same, and is calculated after regressing callback status (0-1) on dummy variables for each university where the applicant obtained her bachelors degree from, using robust standard errors. * indicates a university ranked in the top 200 according to the QS University World Rankings. 